\title{
Upper ocean response to typhoon Kujira (2015) in the South China Sea by multiple means of observation*
}

\author{
GUO Jie ${ }^{1,2,3, * *}$, ZHANG Tianlong ${ }^{1,4}$, XU Chenqi ${ }^{1,4}$, XIE Qiang ${ }^{5}$ \\ ${ }^{1}$ Key Laboratory of Coastal Environmental Processes and Ecological Remediation, Yantai Institute of Coastal Zone Research \\ (YIC), Chinese Academy of Sciences (CAS), Yantai 264003, China \\ ${ }^{2}$ Shandong Key Laboratory of Coastal Environmental Processes, YICCAS, Yantai 264003, China \\ ${ }^{3}$ Center for Ocean Mega-Science, CAS, Qingdao 266071, China \\ ${ }^{4}$ University of Chinese Academy of Sciences, Beijing 100049, China \\ ${ }^{5}$ Institute of Deep-sea Science and Engineering, CAS, Sanya 572000, China
}

Received Apr. 2, 2019; accepted in principle Jun. 4, 2019; accepted for publication Aug. 20, 2019

(C) Chinese Society for Oceanology and Limnology, Science Press and Springer-Verlag GmbH Germany, part of Springer Nature 2020

\begin{abstract}
The impact of typhoon Kujira (2015) on the ocean environment around Yongxing Island in the South China Sea was observed using multiple-satellite sensors and on-site data. A subsurface buoy and Agro float were located to the left and lower right of the track of the typhoon. Satellite observations revealed sea surface cooling of up to $2.5^{\circ} \mathrm{C}$, a maximum decrease in sea surface salinity of 2 in the main study area because of heavy rain, and increases in the chlorophyll concentration induced by the slow-moving typhoon with a maximum observed instantaneous wind speed of $35.1 \mathrm{~m} / \mathrm{s}$. The sea surface temperature to the right of the typhoon track changed more than that on the left owing to a right bias of the typhoon associated with coupling of the typhoon with wind stress on the sea surface. In the ocean interior, there was obvious downwelling at $24.7 \mathrm{~m}$ and upwelling at a depth of $35.7 \mathrm{~m}$ with the vertical entrainment and agitation of the typhoon, and the effects extended to different depths of up to more than $1000 \mathrm{~m}$. When the typhoon passed through the main study area, the maximum flow velocity change at depths of 51 and $660 \mathrm{~m}$ was about 0.44 and $0.04 \mathrm{~m} / \mathrm{s}$, respectively. The typhoon affected the flow field to a depth of $660 \mathrm{~m}$ as it formed and decayed in $11 \mathrm{~h}$, moved at an average speed of $60 \mathrm{~m} / \mathrm{h}$, and affected the sea surface over a range exceeding $700 \mathrm{~km}$ as it moved slowly and stayed at sea for $2 \mathrm{~d}$. Vertical entrainment and agitation generated by the typhoon, as well as rainfall, cooled the sea surface. This inhibited the strengthening of the typhoon, but the energy transmitted to the ocean led to divergence-convergence flow from a shallow to deep layer.
\end{abstract}

Keyword: typhoon Kujira (2015); downwelling; upwelling; flow field; wind field; salinity; temperature

\section{INTRODUCTION}

The oceanic response to tropical cyclones (TCs) has attracted considerable attention because of its importance to environmental and ecological protection. The rapid development of remote sensing satellites and the fusion of various remote sensing data have clarified the effects of typhoon transits on coastal oceans (Herbeck et al., 2011; Guo et al., 2018). Over a reasonably short period, a typhoon can alter the structure of oceanic water (Price, 1981; Price et al., 1994; Dickey et al., 1998; Li et al., 2012), reduce the sea surface temperature (SST) (Stramma et al., 1986; Shay et al., 2000; Lin et al., 2003, 2005; Shang et al., 2008; Mei et al., 2012; Knaff et al., 2013; Domingues et al., 2015; Li et al., 2015; Wei et al., 2015), increase sea surface salinity (SSS) (Knaff et al., 2013; Liu et al., 2014; Yue et al., 2018), enhance sediment transport (Chang et al., 2001; Bian et al., 2010; Liu et al., 2011), and boost phytoplankton blooms (Price et al., 1994; Iverson et al., 1997; Chu et al., 2000; Zheng and Tang, 2007; Byju and Kumar, 2011; Lin et al., 2012; Zhao et al., 2013; Li et al., 2015) in the affected marine area.

\footnotetext{
* Supported by the National Natural Science Foundation of China (Nos. 41576032, 41176160), the International Cooperation, CAS, ChineseForeign Cooperation in Key Projects (No. 133337KYSB20160002), and the National Key R\&D Program of China (No. 2017YFC1405600)

** Corresponding author: jguo@yic.ac.cn
} 

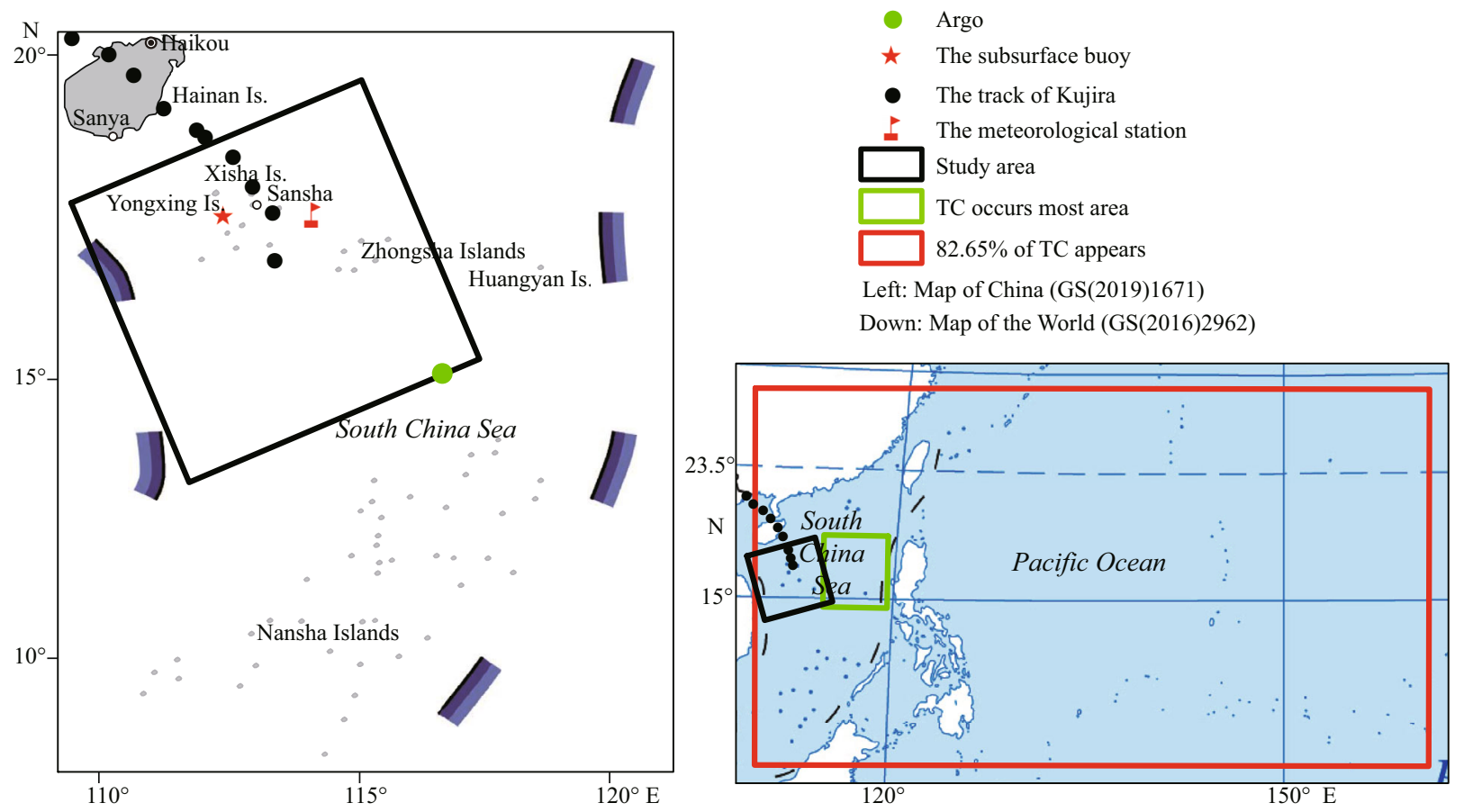

Fig.1 Maps showing the study area

The area of SAR coverage is shown by a black rectangle. The green rectangle indicates the region with the highest frequency of TCs; the red rectangle region shows the $82.65 \%$ of TCs. Black dots: the track of typhoon Kujira. Red star: the location of a subsurface buoy. Green dots: the location of an Argo float. Red flag: the location of a meteorological station.

The response of the upper ocean to the passage of a hurricane can be divided into two stages: a forced stage and a relaxation stage (Gill, 1984; Price et al., 1994). In the forced stage, the strong winds of typhoons stir the upper ocean through local entrainment and vertical mixing and other nonlocal effects (e.g., upwelling (Sun et al., 2009), and horizontal advection (Yang et al., 2010; Sun et al., 2014)), thus cooling the surface water (Price, 1981; Sun et al., 2009; Li et al., 2012; Ye et al., 2018). Price (1981) believed that entrainment caused $85 \%$ of the irreversible heat flux flowing into the mixing layer (ML), with air-sea heat exchange accounting for the remainder. Rabe et al. (2015) believed that the effects of wave driven turbulence by typhoons was one of the causes of changes in the upper ocean. Some scholars consider that the mechanism of the response of oceans to typhoons is Ekman pumping (Xu et al., 2018) or wind-pump effects (Ye et al., 2019). Chang and Anthes (1978) supposed that SST cooling may reduce or even shut down heat fluxes from the ocean to the atmosphere, thus affecting the evolution and intensity fluctuations of typhoons; i.e., a negative feedback of the ocean. In the relaxation stage, typhoon-induced near-inertial motions are dominant (Guan et al., 2014; Rayson et al., 2015; Shen et al., 2017; Yang et al., 2019).
The South China Sea (SCS) is the largest semienclosed marginal sea in the tropical western Pacific (Yang et al., 2015). According to statistics for the SCS from 1949 to 1981, TCs over the SCS accounted for $42.5 \%$ of those over the whole western Pacific, and about $41.1 \%$ of the TCs over the SCS are at a typhoon intensity level (Guan and Xie, 1984). An inferential statistical study on the climate of TC activities in the northwestern Pacific that conducted using data from 2029 TCs during a 60-year period (1949-2008) (Wei and Tang, 2011), found that although about $82.65 \%$ of TCs occurred within the region $5^{\circ} \mathrm{N}-25^{\circ} \mathrm{N}, 110^{\circ} \mathrm{E}-160^{\circ} \mathrm{E}$, TCs originated most frequently within the region $14^{\circ} \mathrm{N}-19^{\circ} \mathrm{N}$, $115^{\circ} \mathrm{E}-120^{\circ} \mathrm{E}$; i.e., within a small $5^{\circ} \times 5^{\circ}$ area west of Luzon in the northeastern SCS (Fig.1). As part of a 10-year (2004-2013) field investigation undertaken by the South China Sea Institute of Oceanology, Chinese Academy of Sciences (SCSIO, CAS), an observational network was established and developed to record oceanographic and meteorological observations (Yang et al., 2015; Zeng et al., 2015). The acquired oceanographic and meteorological data support the study of the response of the SCS to typhoons.

Typhoon Kujira formed in the middle of the SCS on June 21, 2015, when its intensity was classified as 
that of a severe tropical storm (STS; maximum average wind speed near the center of $25 \mathrm{~m} / \mathrm{s}$, level 10). Its center (June 21, 2015 at 03:00 Universal Time Coordinated (UTC)) was located in the middle of the SCS $\left(15^{\circ} 54^{\prime} \mathrm{N}, 111^{\circ} 30^{\prime} \mathrm{E}\right)$, about $140 \mathrm{~km}$ southwest of Yongxing Island (YXI), China. The typhoon landed on the coast near the city of Wanning in Hainan Province at 10:50 UTC on June 22, and it gradually moved toward Vietnam on June 23. The movement speed of the typhoon at sea level was about $2.8 \mathrm{~m} / \mathrm{s}$ while the rainfall was $100-180 \mathrm{~mm}$ according to recordings from China's typhoon network (http:// typhoon.weather.com.cn/). The typhoon was adjacent to the western side of an area of recurrent TCs (Zheng and Tang, 2007) shown in Fig.1, and its path crossed areas of fisheries, seawater aquaculture, and ecological protection in the SCS. The black rectangle encompassing the Yongxing Island area (YXIA) defines the main study area (MSA), which is covered (over $700 \mathrm{~km}$ in diameter) by synthetic aperture radar (SAR). A red flag, red star, and green point respectively show the locations of the meteorological station, subsurface buoy, and Argo float.

The main goal of this paper is to deepen our understanding of the oceanic response driven by typhoon-induced winds. The emphasis is on the effect of typhoons on subsurface processes and structures, such as upwelling, pumping, sea temperature (ST) distribution, salinity (SAL) distribution, and flow fields, at different depths. To this end, we assess the oceanic conditions (i.e., SST, SSS, chlorophyll concentration (chl), flow field, SAL, and ST at different depths) before (pre-storm), during, and after (post-storm) the passage of typhoon Kujira across the YXIA using synergistic multi-satellite remote sensing observations and in situ measurements. We focus on the effects of downwelling and pumping on ST and SAL at the subsurface of the ocean around YXI that can be attributed to the slowly moving typhoon Kujira.

The remainder of the paper is arranged as follows. Section 2 briefly describes the remote sensing, meteorological station and on-site data used in the study and outlines the adopted methodology. Section 3 presents results of the impact of typhoon Kujira on the surface and subsurface of the ocean in the main study area. Section 4 provides an account of the effects of typhoon Kujira on the surface and subsurface oceanic structure, confirming the existence of downwelling and pumping. Section 5 summarizes the main results of the analysis.

\section{DATA SET AND METHODOLOGY}

\subsection{Satellite observation data}

2.1.1 Ocean surface wind vector and significant wave height (SWH) data

Radarsat-2 data (June 21, 2015, 10:40 UTC, SAR Georeferenced Fine Resolution, cross-polarization $\mathrm{VV}-\mathrm{VH}$ ) with a swath width of $500 \mathrm{~km}$ at a resolution of $100 \mathrm{~m}$ were provided by the Canadian Space Agency. Ascat-L3 provides all-weather daily gridded maps of the $10-\mathrm{m}$ wind speed $(V)$ with spatial resolution of $0.25^{\circ}$ (i.e., approximately $25 \mathrm{~km}$ ). The ocean surface instantaneous wind field was retrieved by a C-band cross-polarized ocean backscatter model (C-2PO) from Radarsat-2 data (Zhang et al., 2012, 2014a, c; Zhang and Perrie, 2014b) and daily average data from Ascat-L3. Ascat-L3 data from 2007 onward are available at http://www.remss.com/missions/ ascat/.

OSTM/Jason-2 was launched on June 20, 2008 and it makes along-track altimetric measurements every $1 \mathrm{~s}$ of the SWH and wind speed modulus in delayed time or real time (OGDR, OSDR). SWH (C-band) track data (https://www.aviso.altimetry.fr/en/data/ products/windwave-products/gdr-ogdr-osdr-ra2-wwv. $\mathrm{html \# c6703)}$ are used to assess the effect of typhoon Kujira on the sea state in the study area.

2.1.2 SST, SSS, rainfall, and chl obtained from sea surface data

The present paper uses microwave optimally interpolated daily averaged SST data having a resolution of $25 \mathrm{~km}$, provided by Remote Sensing Systems (available at: www.remss.com), to study typhoon-induced cooling of the sea surface.

The Soil Moisture Active Passive (SMAP) platform was launched in January 2015. Its near-polar orbit allows for complete global coverage of the oceans in $3 \mathrm{~d}$ with a repeat cycle of $8 \mathrm{~d}$. The SMAP SSS data were processed at level $2 \mathrm{C}$ and SAL values were gridded into a level-3 data product. The level-3 grids comprised regular $\left(0.25^{\circ} \times 0.25^{\circ}\right)$ cells and straight averaging of valid level-2C observations was performed. The SMAP SSS data were processed at level $2 \mathrm{C}$, level 3 running an 8-d mean, and level 3 running a monthly mean by Remote Sensing Systems (Li et al., 2013); these data are available at http://data. remss.com/smap. The data resolution is $39 \mathrm{~km} \times 47 \mathrm{~km}$. SSS data of SMAP level-3 running an 8-d mean are 
Table 1 Information of the subsurface buoy and Agro float in the northern SCS

\begin{tabular}{ccccccc}
\hline Buoy & Observation period & Longitude/Latitude & Water depth $(\mathrm{m})$ & Instruments & Range depth $(\mathrm{m})$ & Bin size $(\mathrm{m})$ \\
\hline Mooring & $2015.06 .14-28$ & $16^{\circ} 50^{\prime} 57^{\prime \prime} \mathrm{N} / 110^{\circ} 40^{\prime} 37^{\prime \prime} \mathrm{E}$ & 2000 & ADCP & $469668(\mathrm{ST})$ & \\
& & & & Upward-looking ADCP & $52-452$ (current) & 8 \\
& & & & Downward-looking ADCP & $400-668$ (current) & 4 \\
& & & CTD & $368,469,1198(\mathrm{ST}, \mathrm{SAL})$ & \\
& & & & ST-chain & $948-1398(\mathrm{ST})$ & 50 \\
Agro & $2015.06 .13-29$ & $14^{\circ} 24^{\prime} 32^{\prime \prime} \mathrm{N} / 115^{\circ} 13^{\prime} 59^{\prime \prime} \mathrm{E}$ & 3000 & SBE, FSI & $5.4-1200(\mathrm{ST}, \mathrm{SAL})$ & 5 \\
\hline
\end{tabular}

used in this paper to analyze SSS changes before and during the passage of TP Kujira.

The rainfall (C-band, L3) used in the present paper is Global Precipitation Measurement (GPM) daily average data (having a resolution of $0.1^{\circ} \times 0.1^{\circ}$ ). The GPM mission is an international network of satellites that provide next-generation global observations of rain and snow. Building upon the success of the Tropical Rainfall Measuring Mission, the GPM concept centers on the deployment of a "core" satellite carrying an advanced radar/radiometer system to measure precipitation from space and serves as a reference standard for unifying precipitation measurements from a constellation of research and operational satellites (https://pmm.nasa.gov/dataaccess/downloads/gpm).

Chl data of the sea surface are taken from the website of the European Space Agency (https://www. oceancolour.org/thredds/catalog-cci.html). Fusion data for $8 \mathrm{~d}$, having a resolution of $4 \mathrm{~km}$, are used in this paper.

The present paper uses the remote sensing data listed above to assess the sea surface before, during, and after the passage of typhoon Kujira.

\subsection{In situ observation data}

\subsubsection{Meteorological station data}

The meteorological observation station (indicated by a red flag in Fig.1) on YXI $\left(16^{\circ} 50^{\prime} 24^{\prime \prime} \mathrm{N}\right.$, $112^{\circ} 19^{\prime} 48^{\prime \prime} \mathrm{W}$ ) (Yang et al., 2015) is affiliated with SCSIO, CAS in Fig.1. The data acquired include the 1-min and 3-s averaged wind field, rainfall and rainfall duration. The 3-s averaged wind field data are used for analysis in this paper.

\subsubsection{Subsurface buoy and Argo float data}

Data from a subsurface buoy $\left(16^{\circ} 50^{\prime} 57^{\prime \prime} \mathrm{N}\right.$, $\left.110^{\circ} 40^{\prime} 37^{\prime \prime} \mathrm{E}\right)$ are obtained from SCSIO, CAS (Rayson et al., 2015). The buoy (red star in Fig.1) had two acoustic Doppler current profilers (ADCPs) making upward observations and three SBE37-CTD (conductivity-temperature-depth) instruments. The ADCP data include the time, position (latitude and longitude), ST, and depth (469 and $676 \mathrm{~m}$ ) of the instrument (i.e., the depth of the temperature probe) and currents at depths of 51-668 m. Currents were measured by an ADCP over an upper depth range (51-468 m) with 8-m intervals between depths and over a lower depth range (400-668 m) with $4 \mathrm{~m}$ intervals between depths. A $300 \mathrm{~m}$ temperature chain was placed at a depth between 948 and $1398 \mathrm{~m}$ and recorded the $\mathrm{ST}\left({ }^{\circ} \mathrm{C}\right)$ using a CTD instrument. The SBE37-CTD observations included the time, depth, ST, and SAL at depths of 368, 469, and $1198 \mathrm{~m}$. The subsurface buoy had no ST measurement device and the SAL chain extended to a depth of less than $350 \mathrm{~m}$ (Table 1). The present paper uses the real-time observation data to analyze the effect of typhoon Kujira on oceanic subsurface structures.

The Argo system is a broad-scale global array of temperature/salinity profiling floats and is planned as a major component of the ocean observing system. Floats will cycle to a depth of $2000 \mathrm{~m}$ every $10 \mathrm{~d}$, within a lifetime of 4-5 years for individual instruments. Argo provides accurate and comprehensive measurements of ocean temperature and salinity changes, allowing a systematic assessment of the physical state of the upper ocean. The present paper uses the SAL and ST profile data from Argo float No. $5904566\left(14^{\circ} 24^{\prime} 32^{\prime \prime} \mathrm{N}, 115^{\circ} 13^{\prime} 59^{\prime \prime} \mathrm{E}\right)$ to analyze the effect of typhoons on the subsurface ST and SAL (Fig.1). The depths of the ST and SAL profile are between 5.4 and $1200 \mathrm{~m}$ from an Argo float (Table 1). The Argo float profiles are extracted from the real-time quality-controlled Argo database of the China Argo Real-time Data Center (http:// www.argo.org.cn).

\subsection{Methodology}

This section outlines the methods used to analyze the ocean surface and subsurface responses associated 

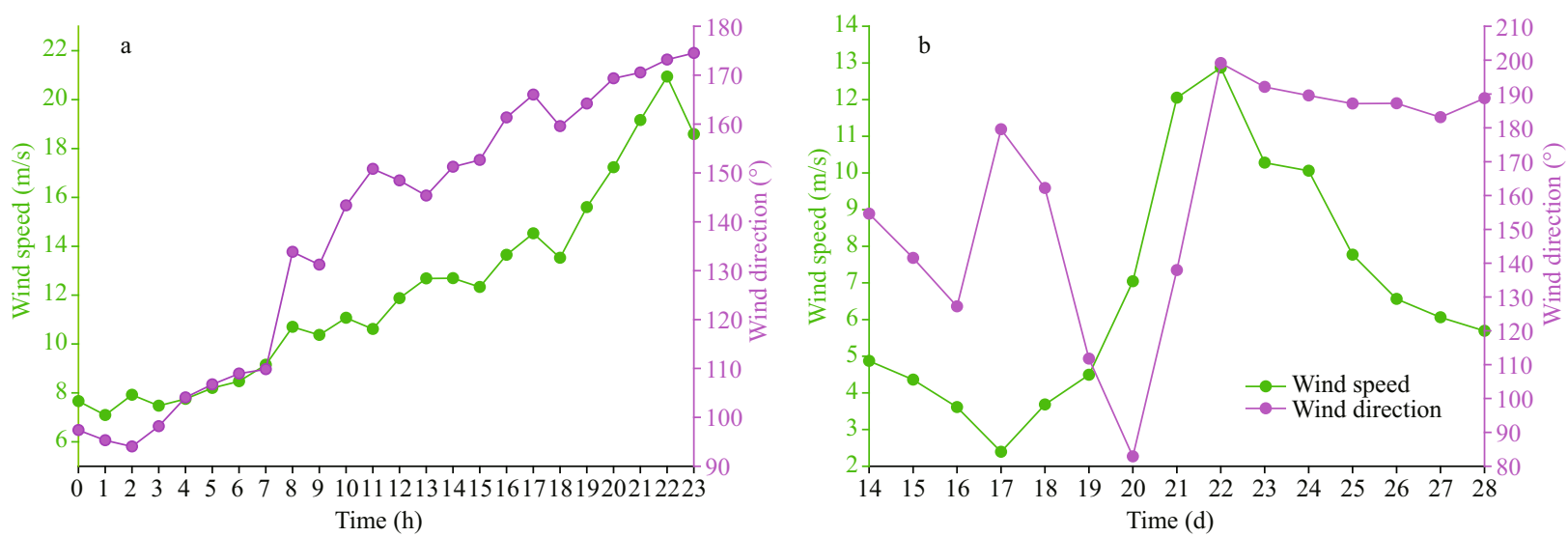

Fig.2 Wind vector observations

a. hourly mean wind speed on June 21, 2015 (UTC: -8 h); b. daily mean wind field during June 14-28, 2015 (3-s mean wind field data).

with the passage of typhoon Kujira using multisatellite, meteorological and buoy observation data. Figure 1 illustrates the track of typhoon Kujira (black dots) in the MSA covered by Radarsat-2 SAR (black rectangle, $\quad 13^{\circ} 30^{\prime} \mathrm{N}-17^{\circ} 27^{\prime} \mathrm{N}, \quad 109^{\circ} 39^{\prime} 36^{\prime \prime} \mathrm{E}-$ $\left.115^{\circ} 16^{\prime} 48^{\prime \prime} \mathrm{E}\right)$. The subsurface buoy and the weather station are respectively on the left and bottom right of the typhoon track. The selection of such observation points is conducive to analyzing the effects of typhoon Kujira on the surface and sub-surface sea water in this region.

\subsubsection{Wind field inversion}

Figure 2 shows the 3-s mean wind field information recorded by the meteorological station on YXI. $V$ gradually increased from 19:00 UTC on June 20 until 14:00 UTC on June 21, reaching a maximum value of $20.94 \mathrm{~m} / \mathrm{s}$ at 14:00 UTC while wind direction gradually increased from 19:00 UTC on June 20 until 15:00 UTC on June 21 (Fig.2a). The daily average $V$ after the passage of typhoon Kujira (June 23-28) was higher than before the arrival of typhoon Kujira (June 14-19) and $V$ reached a maximum on June 21 as shown in Fig.2b. The daily average $V$ rose rapidly and the wind direction changed most during June 20-22 (Fig.2b). The instantaneous maximum $V(35.1 \mathrm{~m} / \mathrm{s})$ of typhoon Kujira reached typhoon level at 10:40 UTC (according to SAR) while the daily average $V(25 \mathrm{~m} / \mathrm{s}$ ) reached the level of an STS (according to ASCAT data).

Typhoon Kujira entered the YXIA at 10:40 UTC on June 21 as observed by the Radarsat- 2 satellite. As derived from the C-2PO with Radarsat-2 data (Fig.3) (Zhang et al., 2012, 2014a, c; Zhang and Perrie, 2014), the highest $V$ near the right at the center of typhoon $\left(16.57^{\circ} \mathrm{N}, 111.78^{\circ} \mathrm{E}\right)$ was $35.1 \mathrm{~m} / \mathrm{s}$, and $V$ on

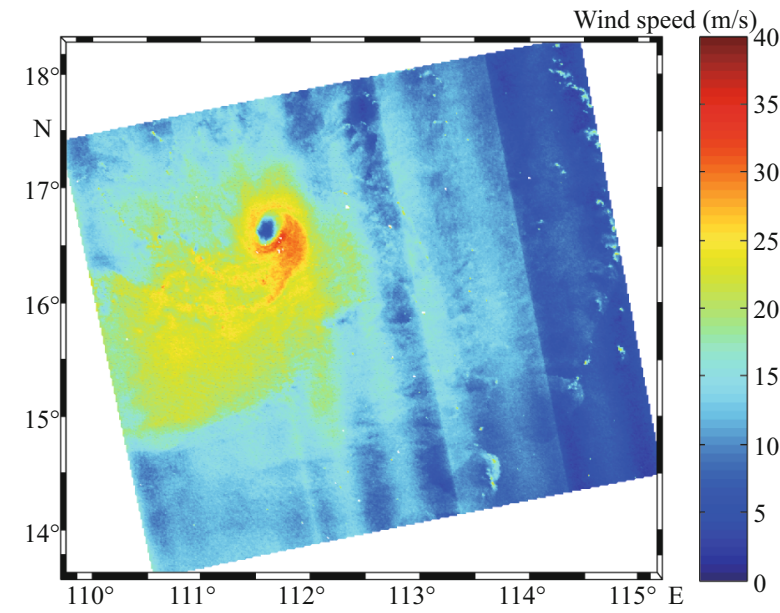

Fig.3 Wind speed retrieved from Radarsat-2 data at 10:40 UTC on June 21, 2015

the right side of typhoon was higher than that on the left side. The maximum difference in $V$ between the two sides of the typhoon track exceeded $10.0 \mathrm{~m} / \mathrm{s}$.

\subsubsection{Variations in the wind vector and SST}

Figure 4 shows the evolutions of the wind vector and SST during the passage of typhoon Kujira during June 19-23, 2015 according to multi-satellite sensor data. Typhoon Kujira originated on June 20, 2015 (Fig.4b) and gradually formed into a strong TS and finally reached typhoon level on June 21 (Fig.4c). The plots are a superposition of the SST and wind field obtained from microwave optimally interpolated daily averaged SST data having a resolution of $25 \mathrm{~km}$ and all-weather daily gridded maps of 10-m wind field with spatial resolution of $0.25^{\circ}$ (i.e., approximately $25 \mathrm{~km}$ ) data. The white areas of the MSA in Fig.4 are the YXI and its surrounding islands (for which there are no data). Before the arrival of typhoon Kujira, the YXIA was characterized by warm 

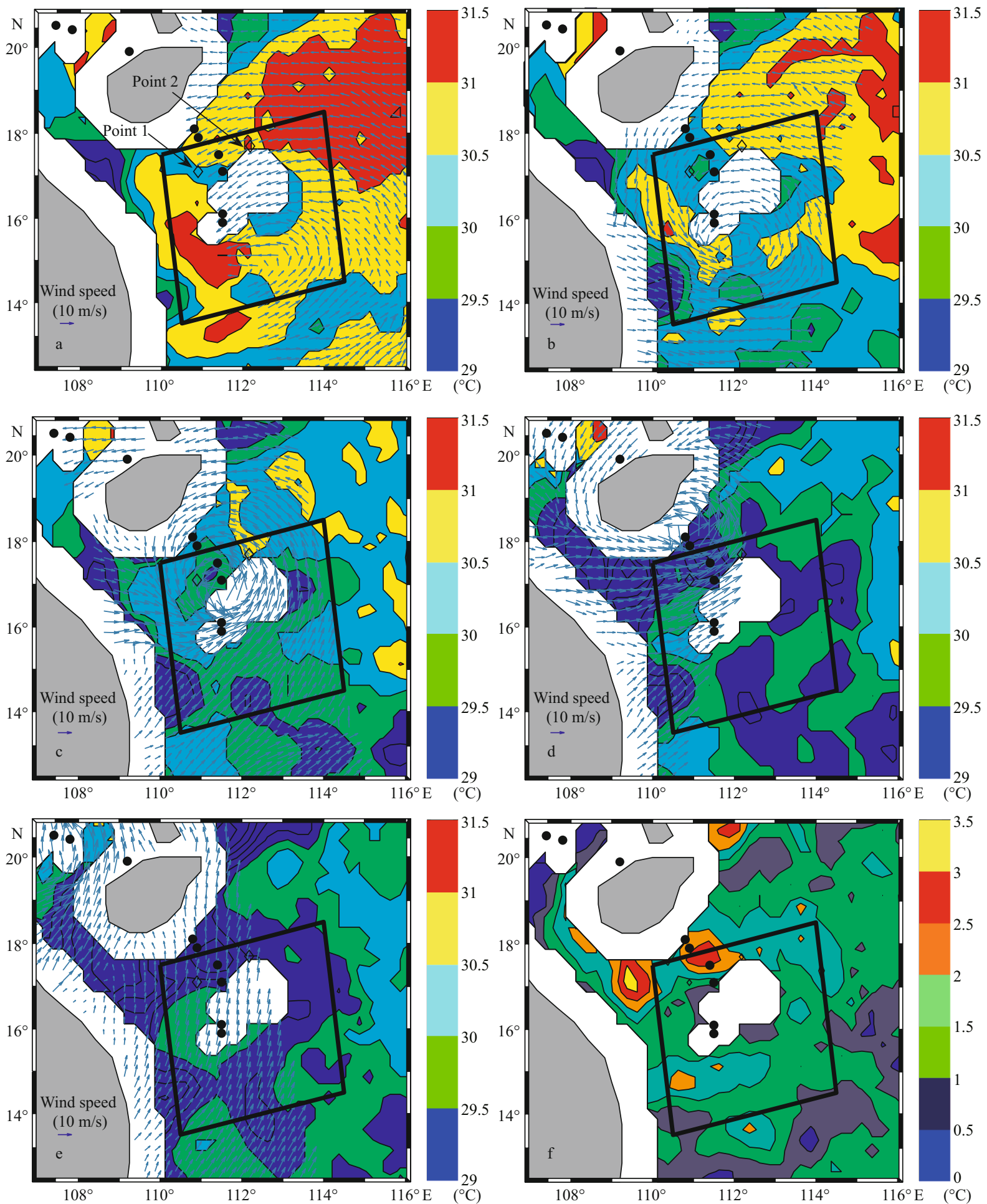

Fig.4 Comparison of wind vectors and SSTs

a. June 19; b. June 20; c. June 21; d. June 22; e. June 23, 2015; f. difference in the SST between 19 and 23 June. The typhoon entered the area shown by the black box on June 21 (in Fig.2a, 2c, 2e, data are from Guo et al., 2018).

SSTs $\left(>30.4^{\circ} \mathrm{C}\right)$ predominately (Fig.4a, June 19$)$. Figure $4 \mathrm{~b}$ shows that following the formation of the TC on June 20, the SST dropped slightly in the MSA because of air-sea interaction. The TC intensified from a severe tropical cyclone to a typhoon in the
YXIA on June 21. At this time, the daily average maximum $V$ increased from 14.6 to $22.4 \mathrm{~m} / \mathrm{s}$ and the maximum SST dropped about $1.21^{\circ} \mathrm{C}$ (Fig. $4 \mathrm{~b} \& \mathrm{c}$ ). The most prominent feature is that the SST of $30^{\circ} \mathrm{C}$ on June 20 (before) fell to $29.5-29^{\circ} \mathrm{C}$ on June 21 

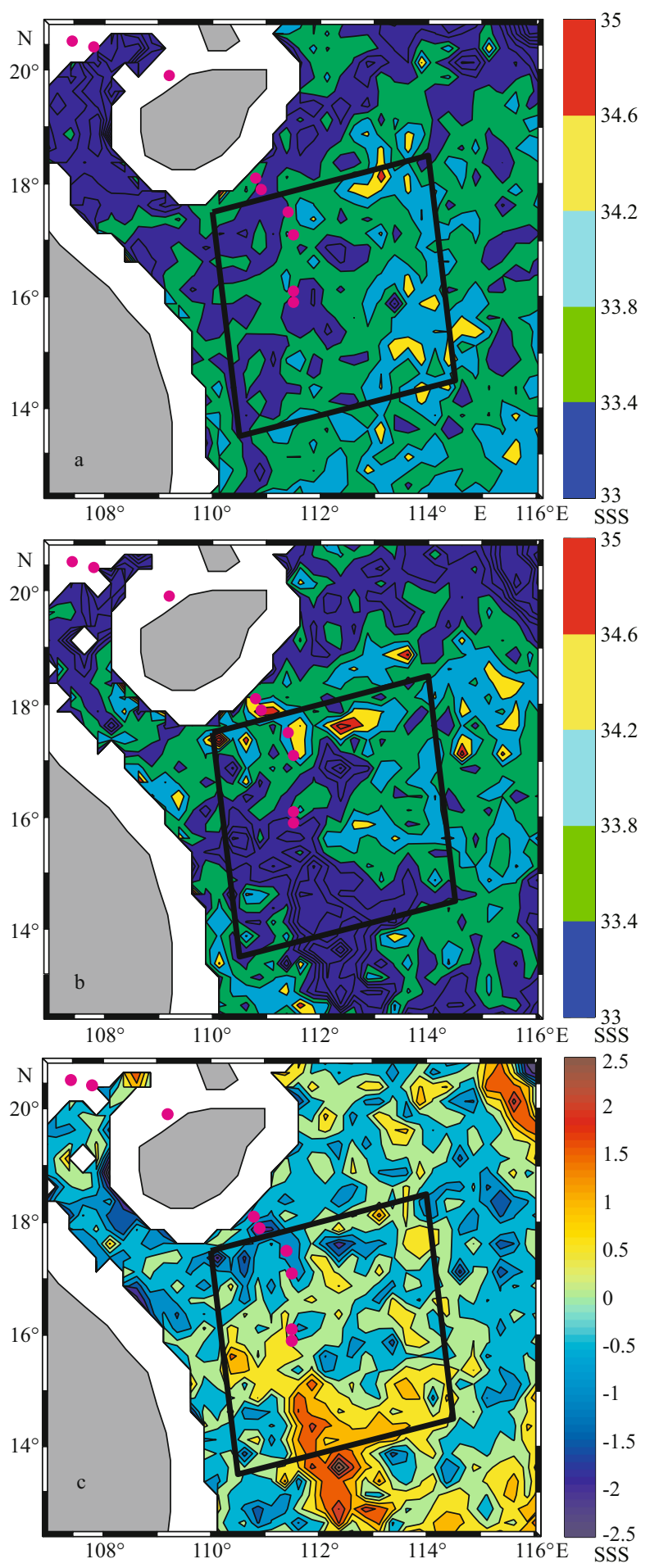

Fig.5 SSS retrieved before (June 10-18) (a) and during and after (June 18-26) the typhoon (b) and the difference (c) in SSS between (a) and (b)

(during) in the MSA. On June 22, the center of the typhoon was about to leave the MSA (June 22, Fig.4d) and the maximum SST fell by another $1{ }^{\circ} \mathrm{C}$ in the MSA. By June 23, the center of the typhoon had completely left the MSA and the area was dominated by an SST of $29^{\circ} \mathrm{C}$ (Fig4e). Figure $4 \mathrm{f}$ shows the difference in the SST in the MSA between before (June 19) and after (June 23) the typhoon. The maximum drop in SST in the MSA before (June 19) and after (June 23) the typhoon was $2.5^{\circ} \mathrm{C}$. Figure 2a shows that the daily average $V$ reached a maximum of $20.94 \mathrm{~m} / \mathrm{s}$ near the weather station at about 14:00 UTC. This location was about $90 \mathrm{~km}$ to the right of the center of the typhoon. Figure 3 shows the typhoon passing through the MSA and wind field retrieval (where the instantaneous maximum wind was $35.1 \mathrm{~m} / \mathrm{s}$ ) from Radarsat-2 at 10:40 UTC on June 21, at which time the typhoon had not reached its maximum intensity. After making landfall at Hainan at about 10:50 UTC on June 22 (Fig.4d), the typhoon gradually decayed. The typhoon subsequently made a second landfall over northern Vietnam at about 03:40 UTC on June 24, as shown in Fig.4e.

\section{RESULT}

\subsection{Responses of the sea surface to the typhoon}

\subsubsection{SSS and chl responses}

Maps of the 8-day running average of SSS data retrieved from SMAP (Meissner and Wentz, 2016) data before (June 10-18, Fig.5a), during, and after (June 18-26, Fig.5b) the passage of typhoon Kujira through the MSA are shown in Fig.5. The typhoon transit time was short and Fig.5b therefore includes the entire process of typhoon formation and disappearance. In comparison with Fig.5a \& b shows an obvious area of low SSS to the left and right (near the Yongxing Island Weather Station) of the typhoon track in the MSA. Figure 5c shows the difference between Fig.5a and Fig.5b; the maximum decrease in the SSS on the typhoon track in the MSA before, during, and after the typhoon is 2 . Negative values in Fig.5c indicate an increasing value of SSS and the maximum increase in SSS in the MSA is 1.5. There is a red low-salinity zone at the bottom left of the track, and the maximum reduction in salinity is between 1.5 and 2.5.

Maps of the European Space Agency CCI-OC-L3S daily 4-km merged chl data before (June 10-17, Fig.6a), during (June 18-25, Fig.6b), and after (June 26-30 and July 3, Fig.6c) the passage of typhoon Kujira through the MSA are shown in Fig.6a-c. The average value of chl in the MSA in Fig.6a is $0.09 \mathrm{mg} / \mathrm{m}^{3}$ and that in Fig. $6 \mathrm{c}$ is $0.13 \mathrm{mg} / \mathrm{m}^{3}$; i.e., chl was higher after the passage of typhoon Kujira than it 

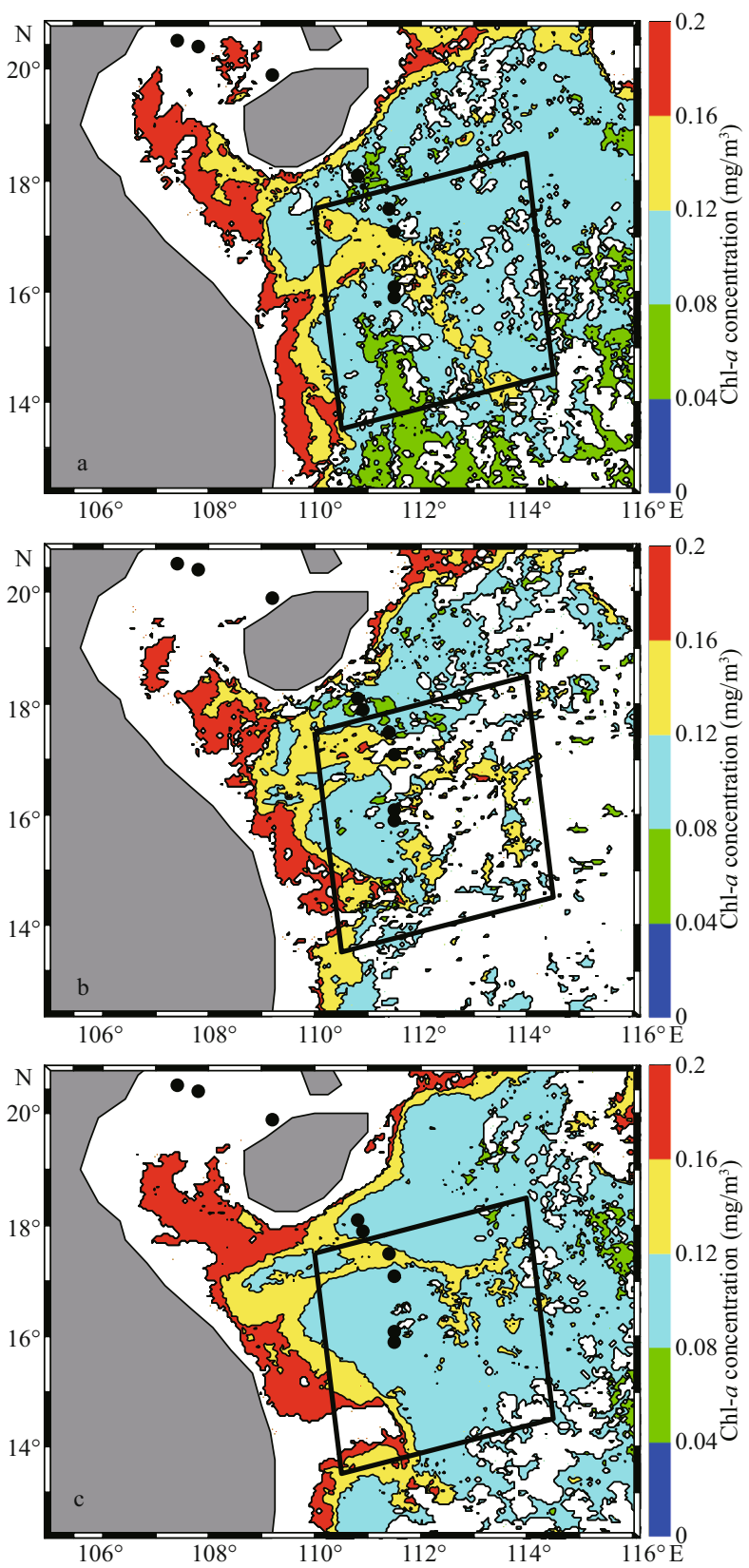

Fig.6 Chl retrieved from CCI-OC-L3S daily data

a. before (June 10-17); b. during (June 18-25); c. after (June 26-30 and July 3) the passage of typhoon Kujira (in Fig.6a-c, data are from Guo et al., 2018).

was before. There are missing data in the MSA in Fig.6b owing to the effect of weather on optical remote sensing data during the passage of the typhoon. Therefore, we cannot judge the distribution of chl in the MSA during the passage of the typhoon.

\subsubsection{SWH and rainfall rate responses}

The SWH was obtained from OSTM/Jason-2 altimeter ground track data before (Track-1: 2015-0618, 23:17:05-23:20:31; Track-2-2015-06, 12:01:05-

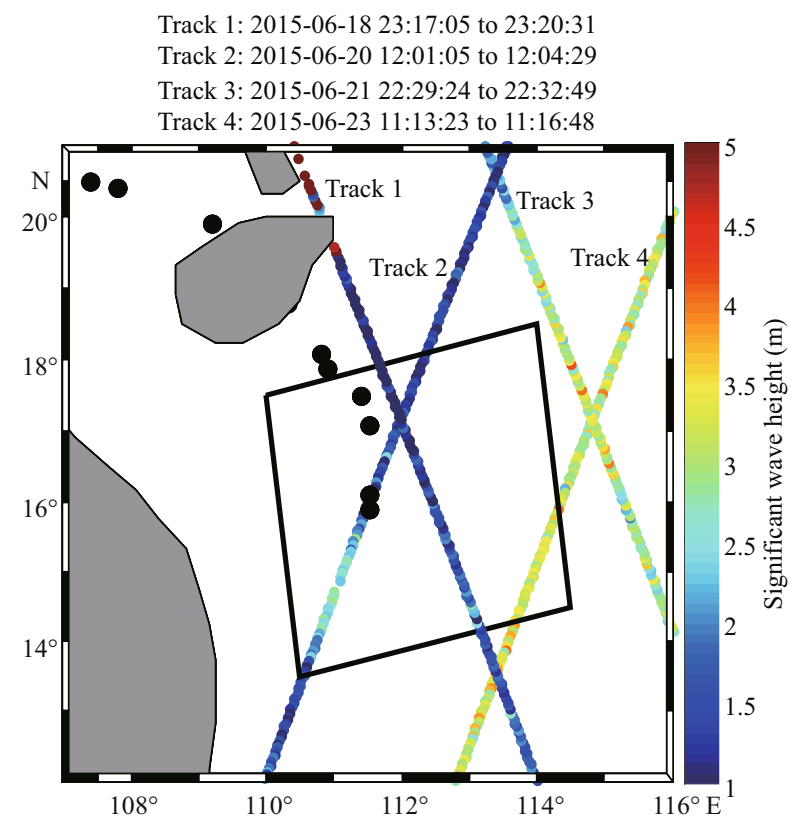

Fig.7 SWH retrieved from Jason-2 track data before (June 18: Track-1 and 20: Track-2), during (June 21: Track-3), and after (June 23: Track-4) the passage of typhoon Kujira in the MSA

12:04:29), during (Track-3-2015-06-21, 22:29:2422:32:49), and after (Track-4-2015-06-23, 11:13:23-11:16:48) the passage of typhoon Kujira through the MSA, as shown in Fig.7. The SWH of 3.5$4.5 \mathrm{~m}$ during the passage of the typhoon is obviously higher than before the event $(0.5-2.5 \mathrm{~m})$ or after at $-0.5 \mathrm{~m}$. The typhoon caused heavy waves (corresponding to sea condition level 5) in the MSA (Fig.7).

Figure 8 shows rainfall during June 19-23. The rainfall in Fig.8a (June 19) is less than $50 \mathrm{~mm} / \mathrm{d}$ on the left and right of the path of the typhoon. The maximum rainfall in Fig.8b (June 20) is more than $150 \mathrm{~mm} / \mathrm{d}$ to the left of the typhoon while that in Fig.8c (June 21), d (June 22), and e (June 23) is more than $100 \mathrm{~mm} / \mathrm{d}$ to the left of the typhoon. Rainfall retrieved from GPM daily average data was mainly concentrated on the left path of the typhoon for June 20-23 in the MSA. Because the typhoon was accompanied by a large area of rainfall, the SSS in the MSA was lower on the left side of the typhoon track than on the right side, as shown in Fig.5b.

Observations from the YXI meteorological station reveal that rainfall increased from 18:00 on June 20 to 15:00 (UTC) on June 21 and the rainfall duration correlated positively with the rainfall amount, as shown in Fig.9a. Figure 9b shows the rainfall rate and rainfall duration change from June 14 to 28 , confirming the results in Fig.9a. This confirms the 

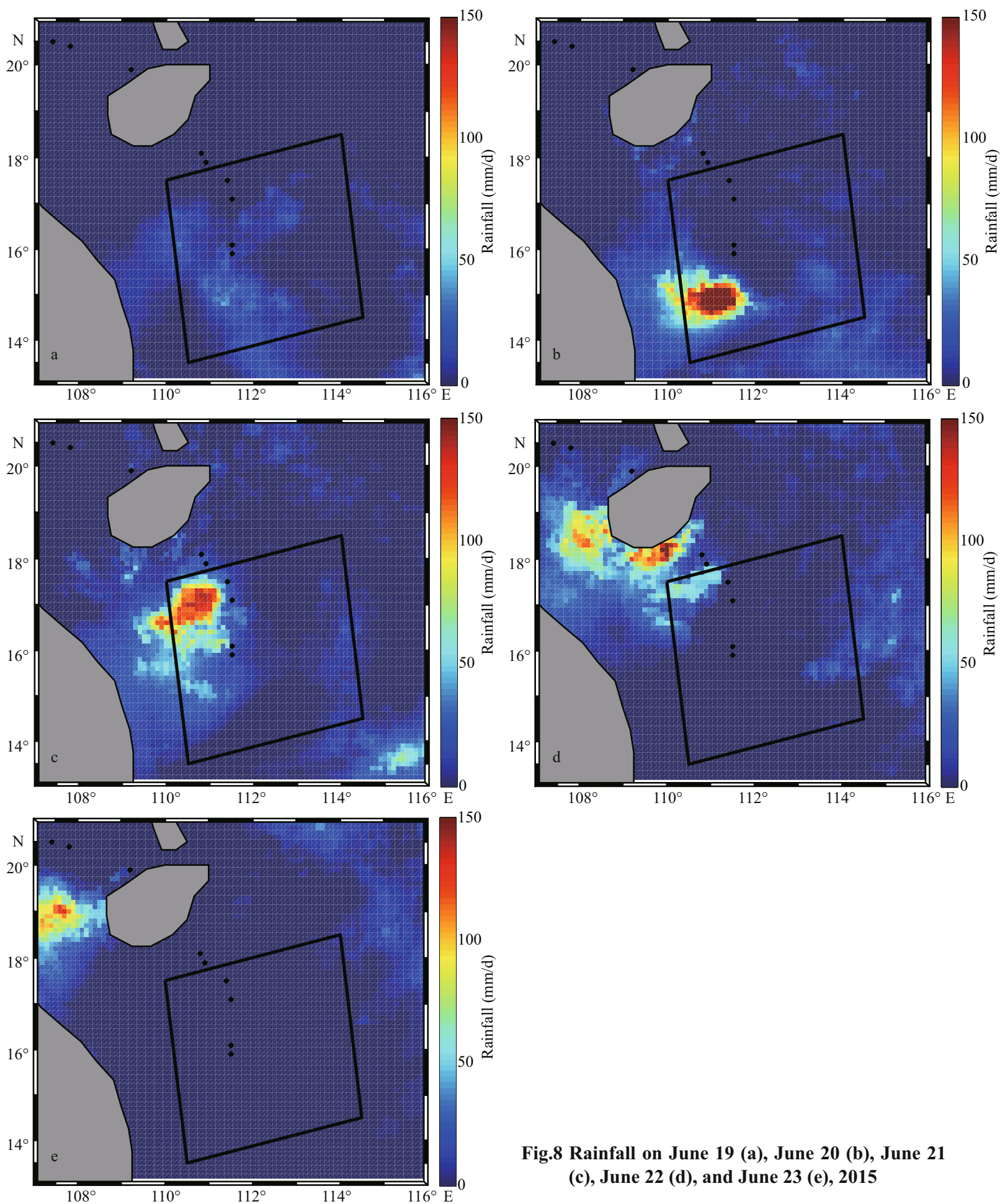

Fig.8 Rainfall on June 19 (a), June 20 (b), June 21 (c), June 22 (d), and June 23 (e), 2015

positive correlation of the rainfall duration and rainfall amount as presented in Fig.9b, with there being high rainfall on the right side of the typhoon track in the MSA on June 17 and 19-22. This was accompanied by a certain period (2000-5000 s) of heavy rainfall $(3-5 \mathrm{~mm} / \mathrm{h}$, similar to $72-120 \mathrm{~mm} / \mathrm{d})$ from June17, 19 to 22.

\subsection{Responses of the subsurface sea water to the typhoon}

Satellite data were only used to analyze the sea surface response to the typhoon. To investigate the subsurface response, we analyze the vertical ST, SAL, and flow field changes measured by the subsurface 

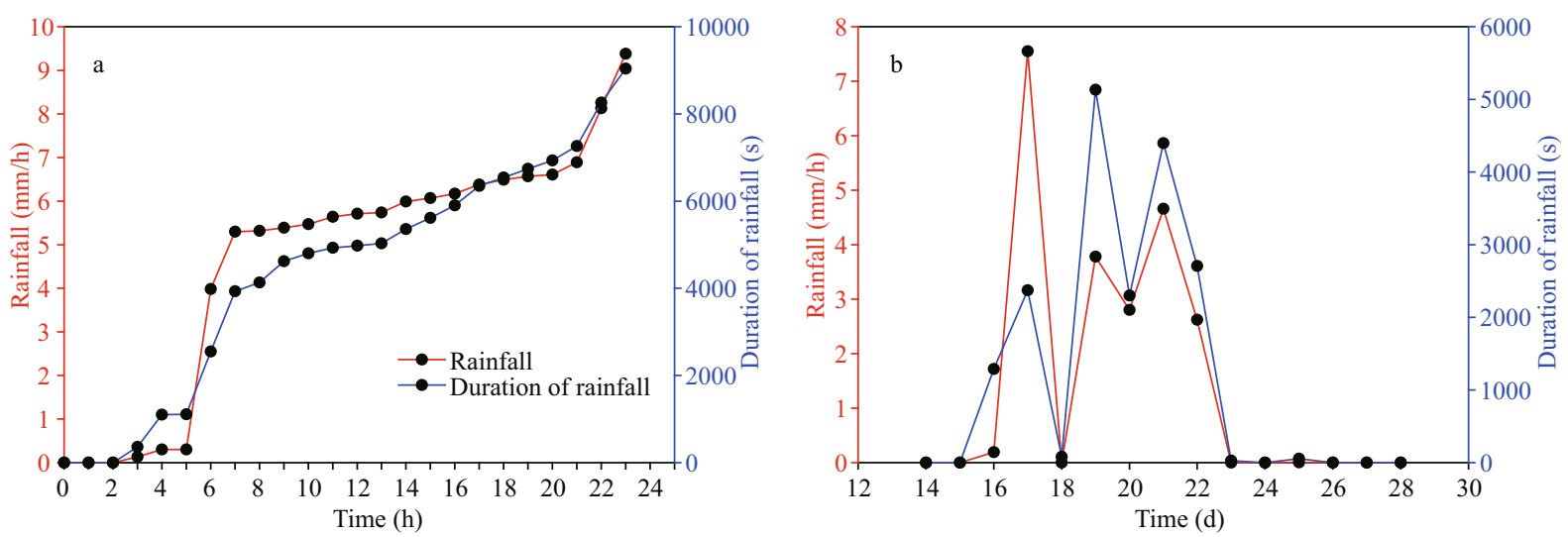

Fig.9 Rainfall and rainfall duration recorded at YXI meteorological observation station on June 21 (a) and from June 14 to 28 (b), 2015

Data in Fig.9a \& b are from Guo et al., 2018.
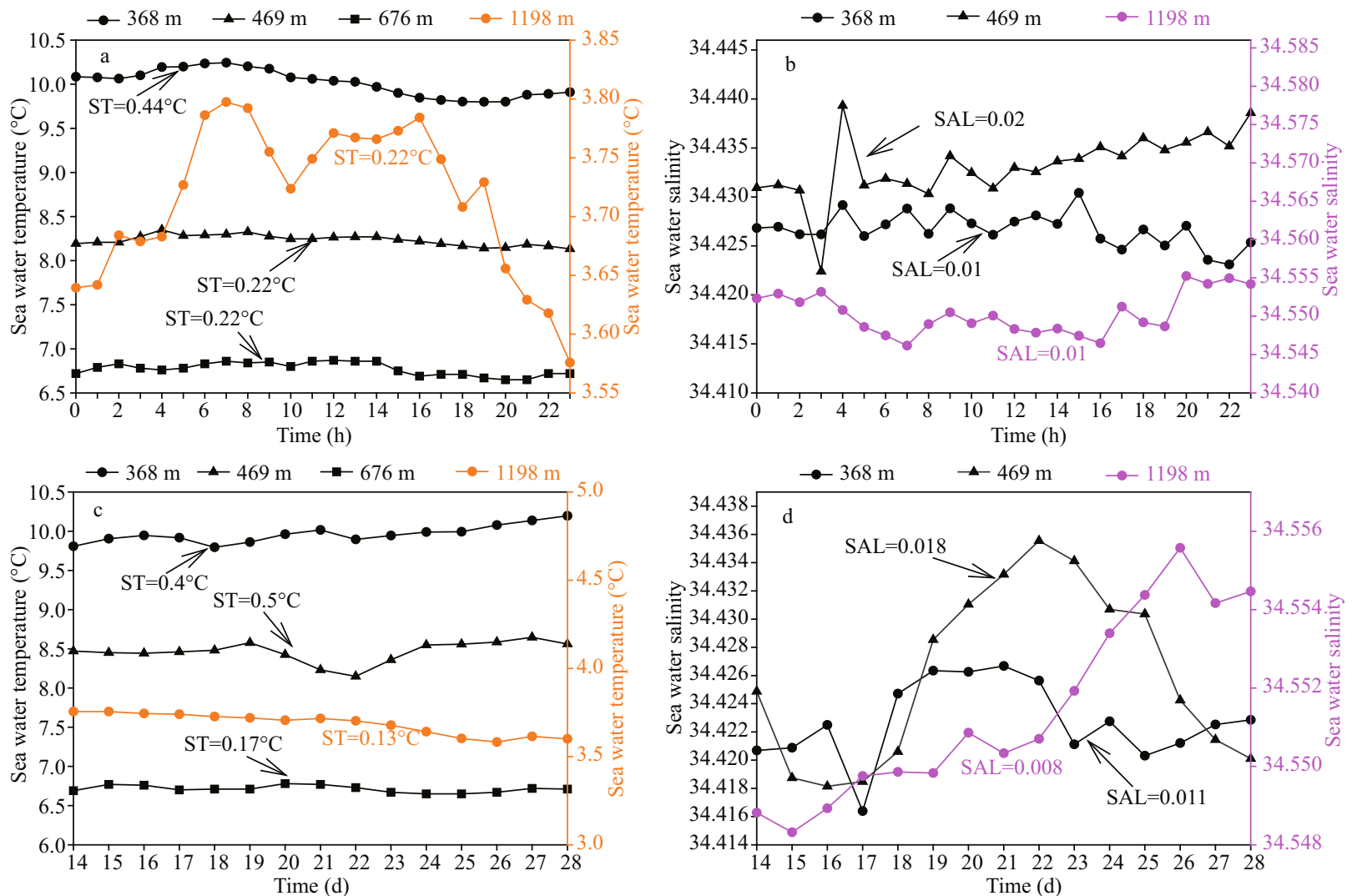

Fig.10 ST and SAL at different depths as measured by SBE37 CTD instruments and the ADCP

Hourly averaged ST (a) and SAL (b) on June 21, 2015 and daily averaged ST (c) and SAL (d) from June 14 to 28, 2015. $\Delta$ ST: maximum amplitude of the variations in ST; $\triangle \mathrm{SAL}$ : maximum amplitude of the variations in SAL.

buoy and Argo float before, during, and after the passage of typhoon Kujira.

3.2.1 Responses of the subsurface-layer ST and SAL were recorded by the subsurface buoy to the typhoon

SBE37-CTD instruments measured the ST and SAL at depths of 368, 469, and $1198 \mathrm{~m}$ before, during, and after the passage of typhoon Kujira. The
STs of ADCP observations at depths of 469 and $676 \mathrm{~m}$ are shown in Fig.10. Between 00:00 and 23:00 on June 21, 2015, the maximum amplitudes of the variations in STs at depths of $368,469,676$, and $1198 \mathrm{~m}$ were $0.44,0.22,0.22$, and $0.22^{\circ} \mathrm{C}$, respectively (Fig.10a). The maximum amplitudes of the variations in SAL at depths of 368, 469, and $1198 \mathrm{~m}$ were $0.01,0.02$, and 0.01 , respectively 
(Fig.10b). The amplitude of the ST change was largest at $368 \mathrm{~m}$, and SAL gradually decreased after 15:00 as shown in Fig.10b. Although the SAL at a depth of $469 \mathrm{~m}$ fluctuated considerably between 03:00 and 04:00, it increased gradually after 12:00. Similarly, ST fluctuated between 03:00 and 05:00 but then gradually decreased after 12:00. The slight increase and decrease in ST at a depth of $1198 \mathrm{~m}$ corresponded to the slight decrease and increase in SAL (Fig. 10a \& b).

Analysis of data for the week after the passage of typhoon Kujira (June 22-28, 2015) reveals that the ST gradually increased relative to the week before the typhoon passage (June 14-20, 2015) at a depth of $368 \mathrm{~m}$ (Fig.10c) and the ST increased by $0.4^{\circ} \mathrm{C}$. Conversely, SAL gradually decreased at a depth of $368 \mathrm{~m}$ after June 22 (Fig.10d) and the average decrease in SAL was 0.011. There was a considerable decrease in ST at a depth of $469 \mathrm{~m}$ from June 19 to 22, which constituted the largest variation in amplitude of $0.5^{\circ} \mathrm{C}$ (Fig.10c). However, this was followed by a substantial recovery during June 2327. Concurrently, SAL at a depth of $469 \mathrm{~m}$ had the opposite tendency, and the amplitude of variation of SAL at this depth was the largest (Fig.10d). The ST at a depth of $676 \mathrm{~m}$ decreased gradually during the week after the passage of the typhoon compared with the week before. During June 22-26, at a depth of $1198 \mathrm{~m}$, the ST was slightly lower and SAL was slightly higher than before the passage of typhoon Kujira (Fig.10c \& d). Table 2 gives the weekly averaged ST and SAL data after the passage of typhoon Kujira at depths of 368, 469, and 1198 m, compared with results for the Northern South China Sea (NCAS) open cruise in 2011 (Zeng et al., 2015). After the passage of the typhoon, at a depth of $368 \mathrm{~m}$, the ST increased by $0.03^{\circ} \mathrm{C}$ and SAL decreased by 0.07 . The ST decreased by $0.54^{\circ} \mathrm{C}$ and SAL increased by 0.03 at a depth of $469 \mathrm{~m}$ while the ST decreased by $0.36^{\circ} \mathrm{C}$ and SAL increased by 0.05 at a depth of $1198 \mathrm{~m}$. These results are consistent with the trends found during the week before the passage of the typhoon.

The above analysis reveals that typhoon Kujira's entrainment and stirring induced pumping that caused seawater downwelling with a high SST and low SSS to settle to $368 \mathrm{~m}$, resulting in a decreased SAL and increased ST. At the same time, upwelling occurred at a depth of $469 \mathrm{~m}$. Water at a depth of $1198 \mathrm{~m}$ was affected by pumping, although both the drop in ST and the rise in SAL were very small. A 300-m ST Chain was placed at a depth greater than $1000 \mathrm{~m}$. The
STs at the various depths observed by the ADCP and SBE37 are shown in Fig.11. It is evident that pumping due to the vertical entrainment of typhoon Kujira had a hysteresis effect with increasing depth from June 22 to 28 at a depth of $676 \mathrm{~m}$ and from June 23 to 28 at depths ranging 948-1 $348 \mathrm{~m}$. However, at a depth of $1398 \mathrm{~m}$, the effect was evident after June 27 as shown in Fig. 11.

\subsubsection{Responses of the subsurface layer ST and SAL} recorded by the Agro float to the typhoon

Argo float results are shown in Fig.12. ST and SAL profiles from CTD observations are presented in Fig. $12 \mathrm{a} \&$ b. There was a stream of high ST and low SAL water entering the ML apparently to $24.7 \mathrm{~m}$ on June 21 during the passage of the typhoon. The high SAL and low ST water upwelling after the passage of the typhoon can be clearly seen in Fig. $12 \mathrm{a} \& \mathrm{~b}$. The typhoon caused the ML to expand from $31 \mathrm{~m}$ underwater to a depth of $35-40 \mathrm{~m}$. The average ST increased by $1.153^{\circ} \mathrm{C}$ and the average SAL decreased by 0.006 . There was a high SAL above 34.5 at depths of 100-200 $\mathrm{m}$ as shown in Fig.12b. When the vertical gradient of a section of a temperature profile is greater than a critical value $\left(0.2^{\circ} \mathrm{C} / \mathrm{m}\right)$ of the thermocline in the same shallow sea $(<200 \mathrm{~m})$, it is determined that this section is a temperature thermocline (TML) (Fang et al., 2013). The depths of the ML and TML changed and the ST and SAL of the ML and TML changed before, during, and after the passage of typhoon Kujira through the MSA as shown in Table 3. The ML deepened and the TML thinned, consistent with the finding of Price (Price, 1991; Price et al., 1994) that hurricane-induced upwelling increases the mixed-layer thickness and entrainment.

Figure 12c and d reveals that typhoon Kujira triggered a different subsurface ST response. The subsurface ST exhibited a three-layer vertical structure. The maximum decreases in ST were $1.2^{\circ} \mathrm{C}$ at depth of $24.7 \mathrm{~m}$ and $0.17^{\circ} \mathrm{C}$ at depths between 250 and $300 \mathrm{~m}$. The ST increased by $0.05-3^{\circ} \mathrm{C}$ at depths of $35.7-180 \mathrm{~m}$ and by $0.04-0.4^{\circ} \mathrm{C}$ at depths of 350 $460 \mathrm{~m}$, as shown in Fig. $12 \mathrm{c}$ and $\mathrm{d}$. These results correspond to an increase of $0.4^{\circ} \mathrm{C}$ found from observations made by the subsurface buoy at $368 \mathrm{~m}$ in Fig.10c. The ST obviously decreases between 460 and $500 \mathrm{~m}$ in Fig.12d, and this corresponds to a decrease of $0.5^{\circ} \mathrm{C}$ in the subsurface buoy observations at $469 \mathrm{~m}$ in Fig.10c. At depths of 1 000-1 $200 \mathrm{~m}$, the ST after the typhoon was significantly lower than the maximum of $0.1^{\circ} \mathrm{C}$ found before the typhoon in 


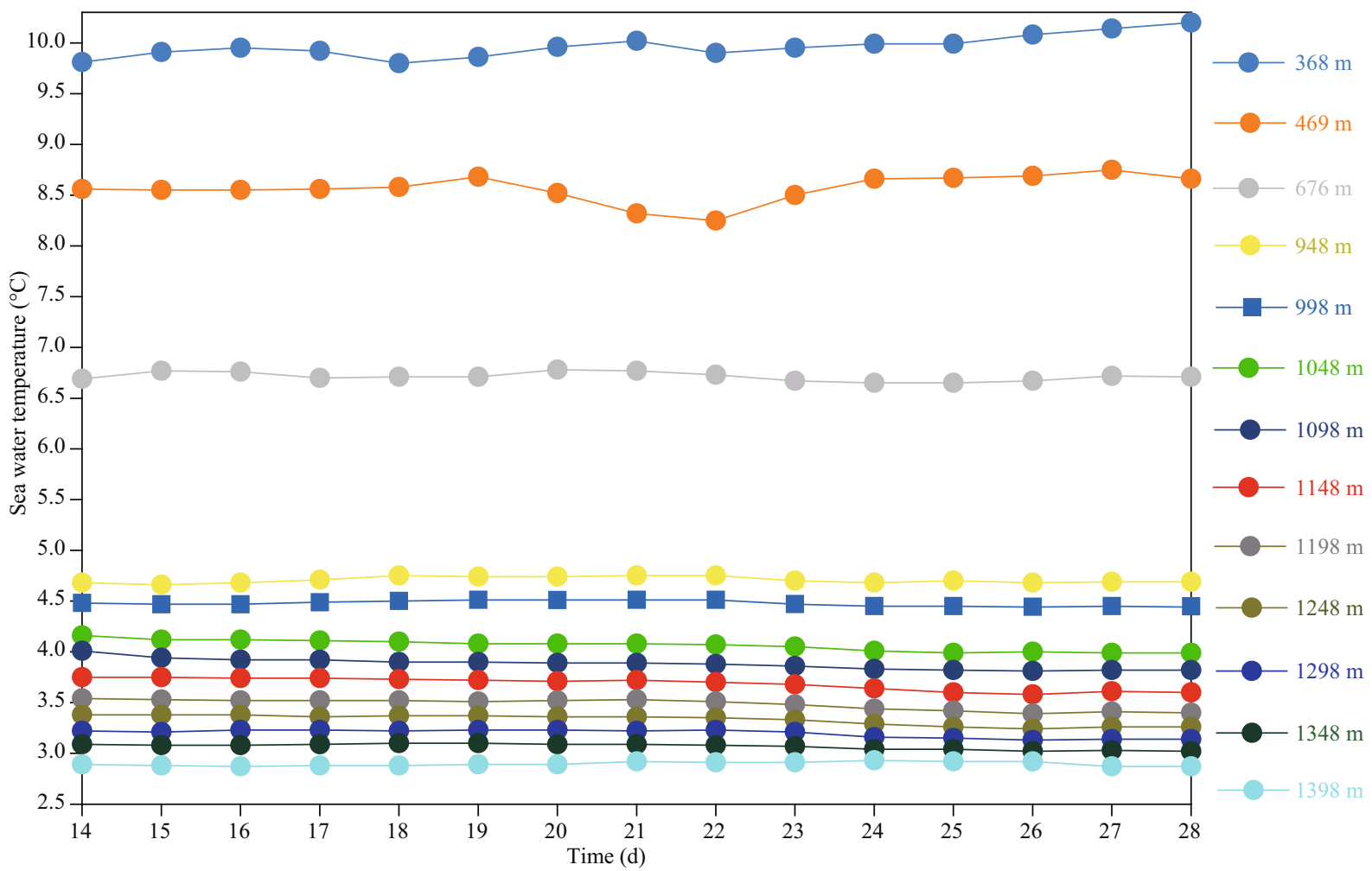

Fig.11 Change in ST with depth as recorded by the subsurface buoy in the week before (June 14-20), during (June 21), and in the week after (June 22-28) the passage of typhoon Kujira

Fig.12d, and this result is consistent with the decreasing trend of the ST after the typhoon compared with the ST before the typhoon at depths between 948 and $1398 \mathrm{~m}$. The Argo SAL profile measurements also confirm an increase in SAL at depths of $35.7 \mathrm{~m}$, $370 \mathrm{~m}, 350-460 \mathrm{~m}$, and $500 \mathrm{~m}$ during and after the typhoon. Furthermore, they confirm a decrease in SAL at depths of $24.7 \mathrm{~m}, 50 \mathrm{~m}$ and $110 \mathrm{~m}$ and $500 \mathrm{~m}$ during the typhoon. The Argo SAL profile measurements has an increase in SAL at depths between 250 and $300 \mathrm{~m}$ during, but has a decrease in SAL at same range after the typhoon.

The above analysis reveals that surface sea water directly settles to a depth of 5.4-24.7 m. Upwelling occurs at depths of $35.7 \mathrm{~m}, 370-500 \mathrm{~m}$ and 1000 $1200 \mathrm{~m}$ in during and after $(24.7 \mathrm{~m}$ and $250-300 \mathrm{~m})$ while downwelling occurs at depths of $24.7 \mathrm{~m}$ (during), 50-110 m (during and after), and 250-300 m (during) in Fig.13.

\subsubsection{Subsurface layer current response to the typhoon}

Flow fields at 51 depths from the upper range and 68 depths from the lower range were observed by the ADCP. Figure 14 shows that the flow velocity decreased with increasing depth during the passage of the typhoon. The changes in the upper flow fields on
June 21 are shown in Fig.14a and the corresponding changes in the lower flow fields are shown in Fig. 14b. Similarly, the changes in the upper flow fields from June 14 to 28 are shown in Fig.14c, and the corresponding changes in the lower flow fields are shown in Fig.14d. The flow was dominated by a northeast flow, and the maximum flow velocity was $0.84 \mathrm{~m} / \mathrm{s}$ at a depth of $50 \mathrm{~m}$ from 04:00 to 14:00 on June 21, as shown in Fig.14a (hourly averaged flow field data). The effect of the typhoon at a depth of $200 \mathrm{~m}$ was considerable, and the flow direction was consistent (Fig.14a). It is obvious that there was a downward trend of the flow rate in the upper layer from 00:00 to 23:00. At 20:00, there was a flow velocity of about $0.2 \mathrm{~m} / \mathrm{s}$ at a depth of $448 \mathrm{~m}$. A downward trend of the flow velocity from 460 to $660 \mathrm{~m}$ (flow velocity: $0.15 \mathrm{~m} / \mathrm{s}$ ) during 15:00-21:00 is evident in the lower flow fields (Fig.14b). The daily averaged upper flow field data from June 14 to 28 , 2015 (Fig.14c) show that the flow directions at depths of 51-450 m were affected by typhoon Kujira for one week after the typhoon's passage and the flow velocity dropped from 0.84 to $0.12 \mathrm{~m} / \mathrm{s}$ with increasing depth from June 21 to 28,2015 . The flow velocity after the typhoon compared with the flow velocity before the typhoon increased by $0.44,0.2,0.1,0.1$, and $0.1 \mathrm{~m} / \mathrm{s}$ 

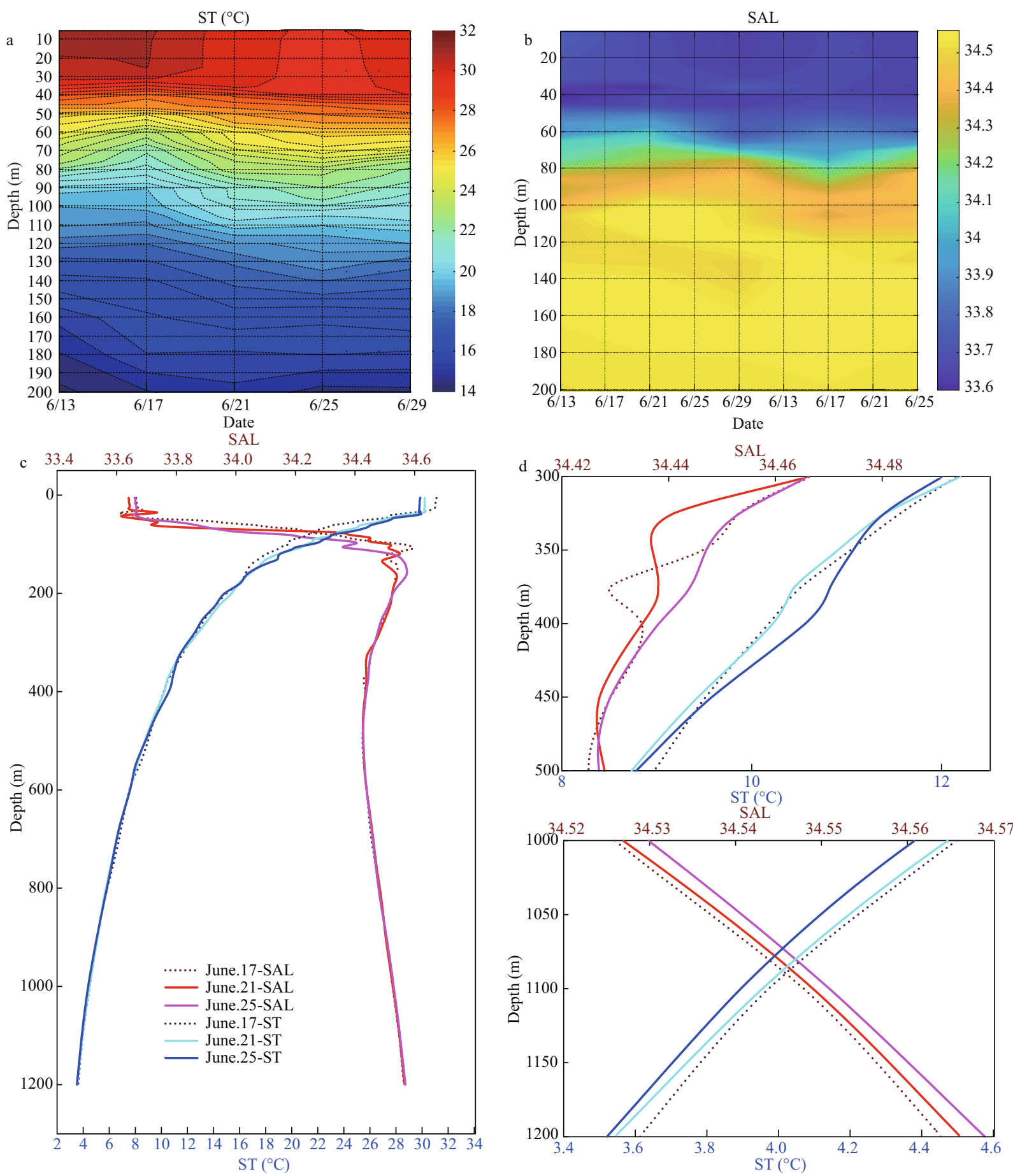

Fig.12 Argo-observed temperature (blue line) and salinity (red line) changes at different depths before (June 17), during (June 21) and after (June 25) the typhoon

at depths of 51, 51-70, 70-100, 100-260, and 260$350 \mathrm{~m}$, respectively (Table 4). The direction of the lower flow field effect from the typhoon was not as obvious as that of the upper flow field in the week after the typhoon's passage at depths of 460-660 m (Fig.14d). However, the flow velocity had an obvious downward trend with a flow velocity of $0.1 \mathrm{~m} / \mathrm{s}$ at depths of 460-650 $\mathrm{m}$ on June 21.

\section{DISCUSSION}

\subsection{Analysis of the wind speed variation and SST response during typhoon formation}

Continuous observations made by the Yongxing Island Weather Station show that the typhoon reached its maximum wind speed at 14:00 UTC on June 21 (Fig.2a). According to the maximum instantaneous 
Table 2 Weekly averaged data of the ST and SAL at different depths, after the passage of typhoon Kujira, compared with NCAS observation data

\begin{tabular}{|c|c|c|c|c|c|c|}
\hline Depth (m) & $\mathrm{ST}\left({ }^{\circ} \mathrm{C}\right)$ & Salinity & $\mathrm{ST}\left({ }^{\circ} \mathrm{C}\right)$ & Salinity & $\Delta \mathrm{ST}\left({ }^{\circ} \mathrm{C}\right)$ & $\Delta$ Salinity \\
\hline & \multicolumn{2}{|c|}{ Data of subsurface buoy } & \multicolumn{2}{|c|}{ Data of NCAS } & Different & Different \\
\hline 368 & 10.03 & 34.42 & 10 & 34.5 & +0.03 & -0.07 \\
\hline 469 & 8.46 & 34.43 & 9 & 34.4 & -0.54 & +0.03 \\
\hline 1198 & 3.64 & 34.55 & 4 & 34.5 & -0.36 & +0.05 \\
\hline
\end{tabular}

wind speed of $35.1 \mathrm{~m} / \mathrm{s}$ inverted from Radarsat-2 data at 10:40 UTC on June 21, it can be judged that a typhoon intensity was reached between 10:40 and 14:00 UTC on June 21, which is essentially consistent with results published on the China meteorological website.

To better study SST changes following the passage of the typhoon through the MSA, point 1 and point 2 were selected either side of the track of the typhoon as shown in Fig.4a. The SST variations from June 19 to 23 are presented in Table 5 . The SST on the right side of the track before the passage of the typhoon was 0.88 and $0.38^{\circ} \mathrm{C}$ higher than that on the left side on June 19 and 20, respectively. During and after the typhoon, the SST difference between the right and left sides of the

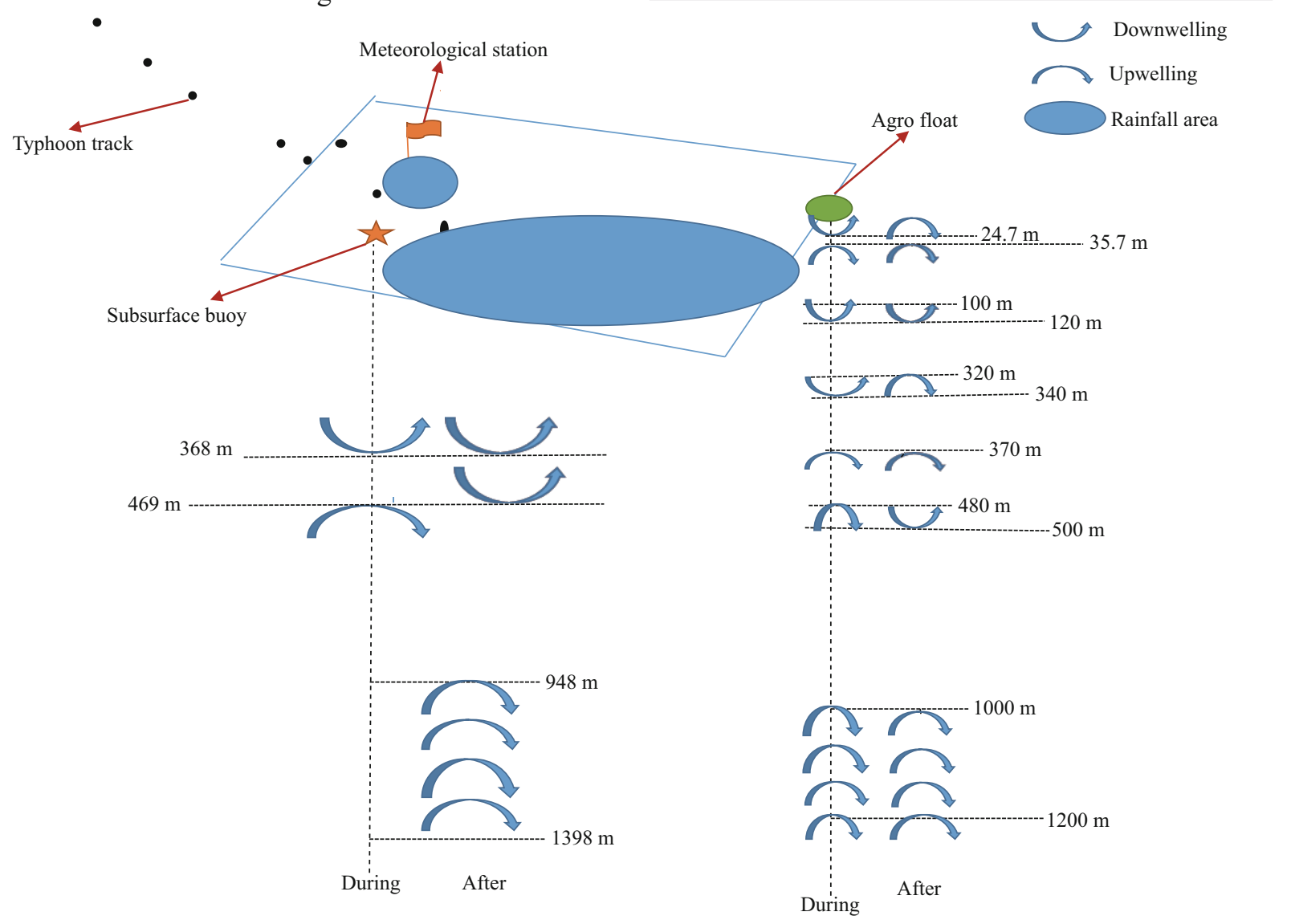

Table 3 Average changes in the ST and SAL in the ML and TML before, during, and after the typhoon

\begin{tabular}{cccc}
\hline Item & Before & During & After \\
\hline ML-depth $(\mathrm{m})$ & $5.6-31$ & $5.5-36$ & $5.2-40$ \\
TML-depth $(\mathrm{m})$ & $32-60$ & $37-56$ & $41-50$ \\
ML-SST $\left({ }^{\circ} \mathrm{C}\right)$ & 30.96 & 30.178 & 29.807 \\
ML-SAL & 33.669 & 33.657 & 33.663 \\
TML-SST $\left({ }^{\circ} \mathrm{C}\right)$ & 27.989 & 27.385 & 27.191 \\
TML-SAL & 33.7075 & 33.657 & 33.764 \\
\hline
\end{tabular}

Table 4 Change in velocity before and after the passage of the typhoon with depth

\begin{tabular}{ccc}
\hline Time & Depth $(\mathrm{m})$ & Flow velocity $(\mathrm{m} / \mathrm{s})$ \\
\hline Before & 51 & 0.4 \\
After & 51 & 0.84 \\
Before & $51-70$ & 0.4 \\
After & $51-70$ & 0.6 \\
Before & $70-100$ & 0.4 \\
After & $70-100$ & 0.5 \\
Before & $100-260$ & 0.2 \\
After & $100-260$ & 0.3 \\
Before & $260-350$ & 0.1 \\
After & $260-350$ & 0.2
\end{tabular}

Fig.13 Idealized sketch of initial fields after storm passage 
Table 5 SST changes at two fixed points during the typhoon transit

\begin{tabular}{cccccc}
\hline Data & June 19 & June 20 & June 21 & June 22 & June 23 \\
\hline Point 1 & 30.57 & 30.24 & 30.08 & 29.36 & 29.14 \\
Point 2 & 31.45 & 30.62 & 30.14 & 29.58 & 29.36 \\
Different between & 0.88 & 0.38 & 0.06 & 0.22 & 0.22 \\
Point 2 and Point 1 & & & & & \\
\hline
\end{tabular}

track was less than that before the typhoon and the SST difference was a minimum of $0.06^{\circ} \mathrm{C}$ on June 21 . The maximum change in the SST on the right side of the typhoon track was $2.09^{\circ} \mathrm{C}$ while that on the left side was $1.43^{\circ} \mathrm{C}$ from June 19 to 23 as presented in Table 5 . The SST response on the right side of the track was stronger than that on the left side as the typhoon windstress vector turned clockwise with time on the right side of the track and was roughly resonant with the mixed layer velocity (Price, 1981). Typhoon Kujira moved at a speed of about $2.8 \mathrm{~m} / \mathrm{s}$ and the sea-air interaction caused the high SST to drop rapidly during the formation of the typhoon (Fig.4b \& c). The vertical entrapment of typhoon Kujira caused pumping, and rainfall that deepened the mixing layer and thinned the thermocline, resulting in upwelling and downwelling

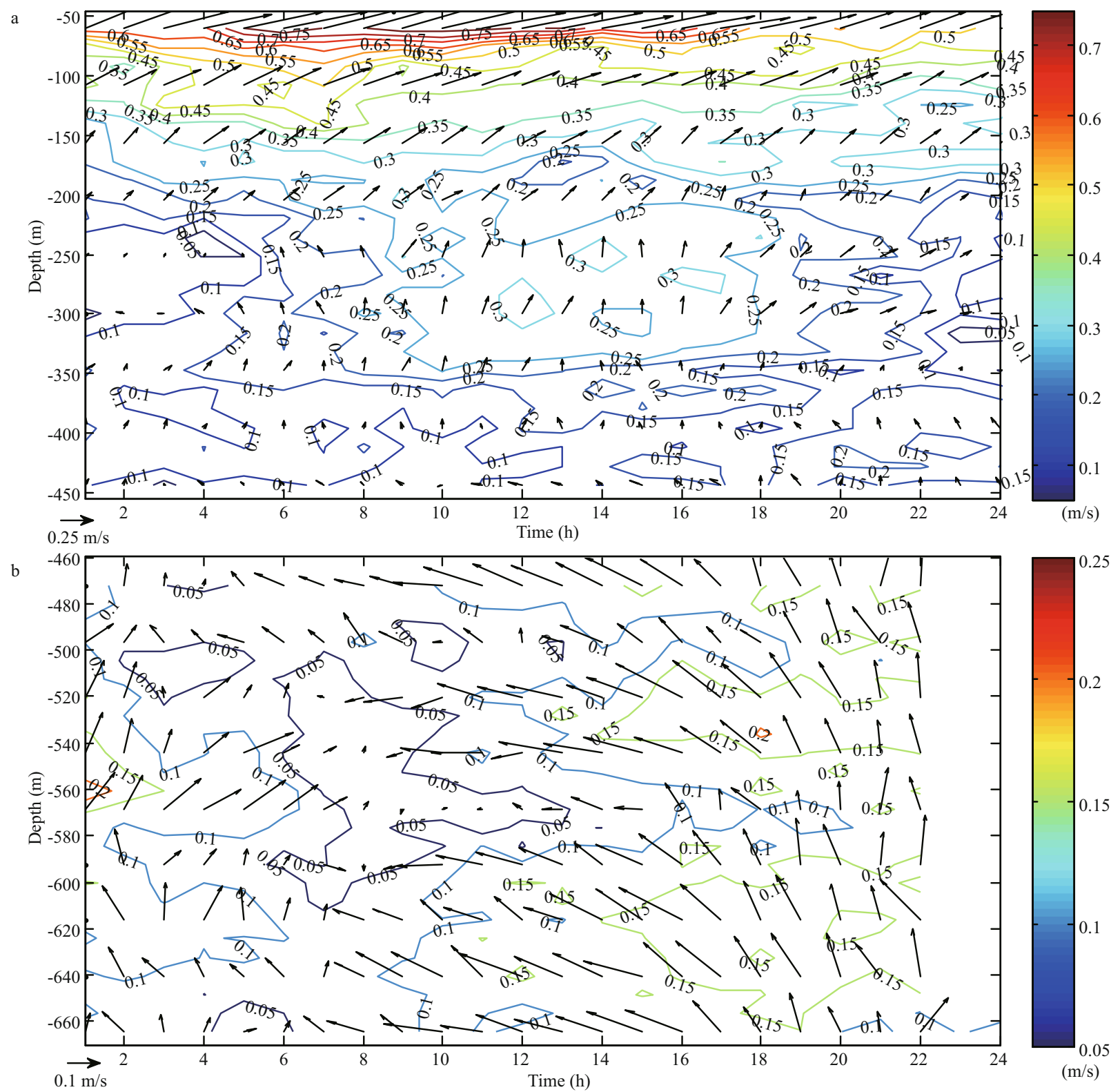

Fig.14 Changes in the upper flow field (a) and lower flow field (b) on June 21, 2015 and those in the upper flow field (c) and lower flow field (d) during June 14-28, 2015

Contour lines represent changes in velocity, and vectors represent changes in flow field 
Fig.14 Continued
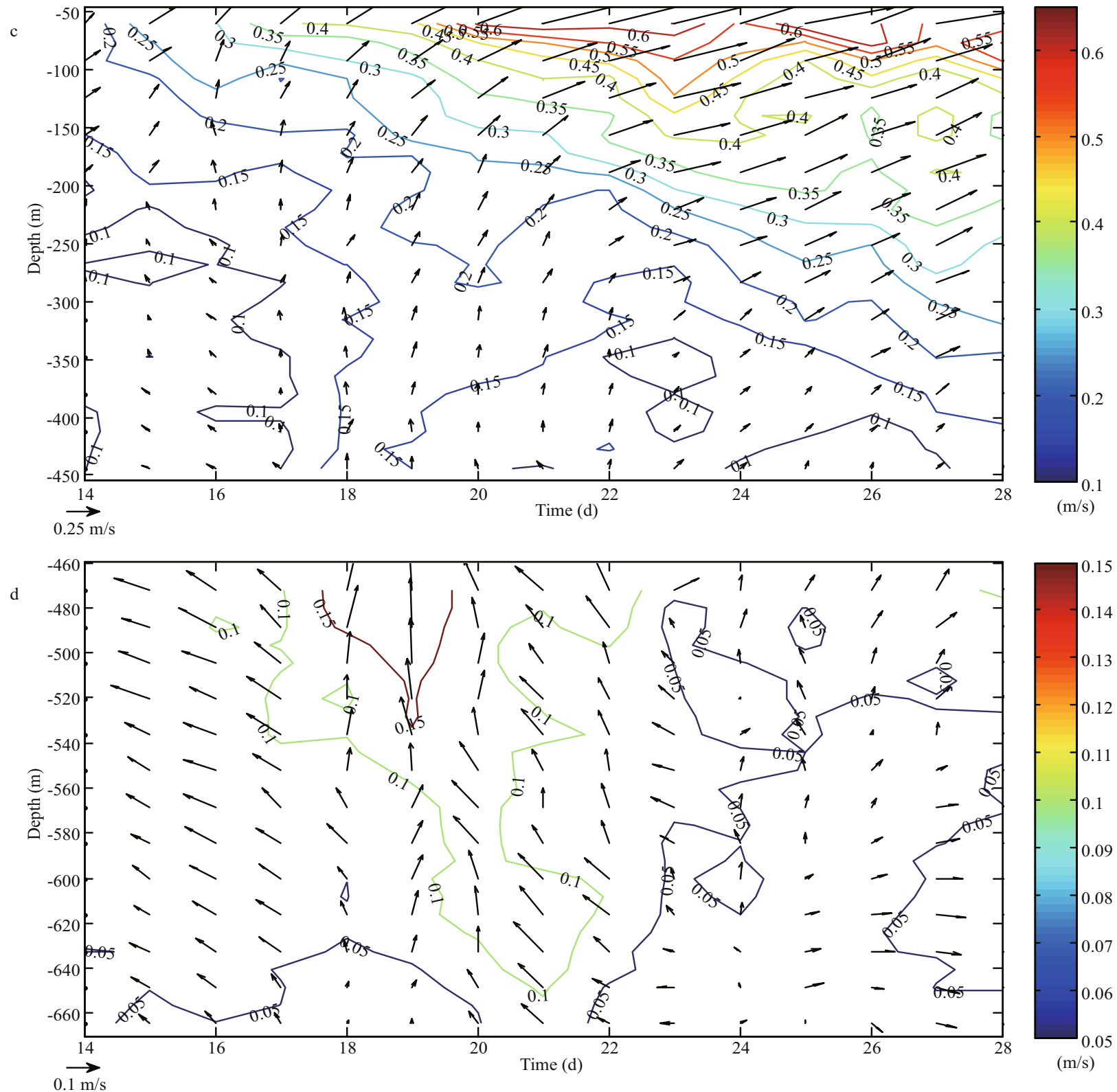

of the transmitting deep layer. This reduced the SST over a large area weakened the typhoon to a strong TC. SST cooling of about $1-2.5^{\circ} \mathrm{C}$ is generally due to vertical entrainment (Price, 1981; D’Asaro et al., 2007; $\mathrm{Li}$ et al., 2016). The results of analysis are consistent with the conclusion drawn by Chang and Anthes (1978) that SST cooling may reduce or even shut down heat fluxes from the ocean to the atmosphere, thus affecting the evolution and intensity fluctuations of TCs; i.e., there is a negative feedback of the ocean.

\subsection{Analysis of the salinity and chl responses during typhoon formation}

The SSS normally increases after a typhoon owing to the vertical entrainment of the typhoon. However, Figure 5 shows that the SSS inverted from remote sensing data decreased after the passage of the typhoon. The remote sensing inversion of the rainfall rate and on-site observations reveal that both sides of the typhoon transit track were accompanied by heavy rainfall of about $100 \mathrm{~mm} / \mathrm{d}$. Owing to the influence of rainfall, the SSS decreased within the range of rainfall during and after the passage of the typhoon, and the maximum reduction amplitude on the right side of the track was about 2 in the MSA. This result is consistent with the conclusions of Sun et al. (2012), and Li et al. (2014). However, the salinity increased in areas not covered by rainfall and the maximum amplitude was 
2. However, we found that the heavy rainfall on the right side of the track was not reflected by the GPM data.

Figure $6 \mathrm{~b}$ shows the distribution of the chl in the MSA during the typhoon and $4 \mathrm{~d}$ after the typhoon. Owing to weather conditions, optical remote sensing data are not complete and cannot be evaluated. However, data for the following $5 \mathrm{~d}$ show that the chl in the MSA and the adjacent coastal area was higher than that before the typhoon in Fig.6c. Our conclusion is basically consistent with the conclusion drawn by Zheng and Tang (2007) that both typhoon winds and rain enhance the production of marine phytoplankton.

\subsection{Analysis of the response of the subsurface layer to the typhoon}

The analysis of flow fields reveals that typhoon Kujira affected the flow field at depths to $660 \mathrm{~m}$ and that the effect remained substantial at depths less than $450 \mathrm{~m}$ in the week after the typhoon's passage. The typhoon affected the flow field to a depth of $660 \mathrm{~m}$ as it formed and decayed over a period of $11 \mathrm{~h}$ and moved at an average speed of $60 \mathrm{~m} / \mathrm{h}$. We clearly see that the energy transferred to the ocean by the vertical entrainment and stirring of the typhoon is transferred downward layer by layer from Fig.13. Therefore, the upwelling and downwelling of seawater at different depths due to the wind pump effect (including vertical mixing and upwelling) and the transfer to the deep sea can be analyzed using the fluctuations of the ST and SAL recorded by the subsurface buoy and Agro float.

A comparison of the ST and SAL data recorded by the subsurface buoy revealed that downwelling occurred at a depth of $368 \mathrm{~m}$ after the typhoon's passage and that the upwelling occurred at a depth of $469 \mathrm{~m}$ as a pumping phenomenon. The effect of upwelling on the ST was found to lag increasingly with increasing depth. The data acquired by the $300-\mathrm{m}$ ST Chain at a depth of $1000 \mathrm{~m}$ indicate that pumping had different degrees of influence on the MSA (Fig.12). Remote sensing data reveal the effect of the typhoon's passage on the sea surface. The typhoon caused the SWH to reach 3.5-4 m, which aided the stirring of seawater. A comparison of meteorological observation data and remote sensing data reveals that the rainfall rate retrieved by remote sensing does not reflect the large rainfall rate on the right side of the track of the typhoon. The SSTs shown in Fig.2c (during the typhoon's passage) and in Fig.2d \& e (after the typhoon's passage) are obviously lower than those before the passage of the typhoon owing to vertical entrainment, air-sea interaction, and rainfall. The SSS shown in Fig.5b (during and after the typhoon's passage) is lower than that before the typhoon (Fig.5a) in the area of rainfall (+), while the SSS in the area without rainfall is higher (-) owing to vertical entrainment in Fig.5c. The decrease in SSS was induced by the intense precipitation associated with typhoon Kujira, because rainfall injects fresh water into the ocean. The above analysis reveals that wind pumping generated by typhoon Kujira contributed substantially to the decrease in SST and the increase in SSS but rainfall also played a role in reducing SSS.

\section{CONCLUSION}

The surface and subsurface physical responses of the ocean to typhoon Kujira were quantified using available multi-satellite observations, weather station observations, and Argo float and subsurface buoy data. The typhoon moved at a speed of about $2.8 \mathrm{~m} / \mathrm{s}$; however, its impact on the YXIA persisted for over a week. Analysis of both satellite observations and onsite data confirms that strong winds increased the SWH and that vertical entrainment and stirring resulted in a maximum decrease in the sea surface temperature of $2.5^{\circ} \mathrm{C}$ while heavy rain resulted in a maximum decrease in sea surface salinity of 2 , leading to upwelling and downwelling of the deep sea. The high temperature and low salinity at the sea surface downwelling directly to $24.7 \mathrm{~m}$, and the ST and SAL of the subsidence are basically consistent with the SST and SSS results of remote sensing inversion. Agro buoy data, with lower ST and higher SAL from the mixed layer to the sea surface, clearly shows an increase in SSS (with maximum amplitude of 2) with no cover by rain area and chl $\left(0.04 \mathrm{mg} / \mathrm{m}^{3}\right)$. The SST decreased not only the immediate vertical entrainment associated with heat extraction and redistribution but also that associated with pumping and persistent upwelling below the ML. However, rainfall reduced the SSS after the passage of the typhoon at rain-covered area. Large-scale rainfall not only dilutes the sea surface salinity but, accompanied by upwelling, also rapidly reduces the sea surface temperature, which inhibits the strengthening of slow-moving $(<2.8 \mathrm{~m} / \mathrm{s})$ typhoons. With a reduction in the sea surface temperature, typhoons lack energy and weaken to TCs within $1 \mathrm{~d}$. In any event, strong vertical entrainment and mixing due to typhoonstrength winds transfer energy to the ocean, strengthening the near-surface ocean current and 
deep transfer accompanied by upwelling and downwelling.

Typhoon Kujira had been moving across the sea surface for less than $2 \mathrm{~d}$, and its initial wind force had just reached typhoon level. However, it transferred a huge amount of energy to the ocean, the typhoon affected the flow field to a depth of $660 \mathrm{~m}$ as it formed and decayed over a period of $11 \mathrm{~h}$ and moved at an average speed of $60 \mathrm{~m} / \mathrm{h}$. Typhoon entrainment induced pumping which affected different depths to about $1 \mathrm{~km}$ for 1 week after the typhoon in buoys and bringing vitality to the sea area of Yongxing Island. The SST response on the right side of the track was stronger than that on the left side as the typhoon windstress vector turned clockwise with time on the right side of the track and was roughly resonant with the ML velocity. The ML deepened and the TML thinned from the subsurface layer. This shallow divergenceconvergence flow can lead to a shallow overturning flow in the upper ocean, potentially affecting largescale ocean circulations and climates.

\section{DATA AVAILABILITY STATEMENT}

Data available on request from the authors.

\section{ACKNOWLEDGMENT}

We thank the South China Sea Institute of Oceanology for providing observation data from the weather station on Yongxing Island, and QI Yiquan of the South China Sea Institute of Oceanology for providing the moored ADCP data. Helpful advice from Dr. LI Xiaofeng is also greatly appreciated.

\section{References}

Bian C W, Jiang W S, Song D H. 2010. Terrigenous transportation to the Okinawa Trough and the influence of typhoons on suspended sediment concentration. Continental Shelf Research, 30(10-11): 1 189-1 199, https://doi.org/10.1016/j.csr.2010.03.008.

Byju P, Kumar S P. 2011. Physical and biological response of the Arabian Sea to tropical cyclone Phyan and its implications. Marine Environmental Research, 71(5): 325-330, https:// doi.org/10.1016/j.marenvres.2011.02.008.

Chang G C, Dickey T D, Williams III A J. 2001. Sediment resuspension over a continental shelf during hurricanes Edouard and Hortense. Journal of Geophysical Research: Oceans, 106(C5): 9 517-9 531.

Chang S W, Anthes R A. 1978. Numerical simulations of the ocean's nonlinear baroclinic response to translating hurricanes. Journal of Geophysical Research, 8(3): 468480.

Chu P C, Veneziano J M, Fan C W, Carron M J, Liu W T. 2000.
Response of the South China Sea to tropical cyclone Ernie 1996. Journal of Geophysical Research, 105(C6): 13 99114009.

D'Asaro E A, Sanford T B, Niiler P P, Terrill E J. 2007. Cold wake of hurricane Frances. Geophysical Research Letters, 34(15): L15609, https://doi.org/10.1029/2007GL030160.

Dickey T, Frye D, McNeil J, Manov D, Nelson N, Sigurdson D, Jannasch H, Siegel D, Michaels T. Johnson R. 1998. Upper-ocean temperature response to hurricane Felix as measured by the Bermuda testbed mooring. Monthly Weather Review, 126(5): 1 195-1 201.

Domingues R, Goni G, Bringas F, Lee S K, Kim H S, Halliwell G, Dong J L, Morell J, Pomales L. 2015. Upper ocean response to Hurricane Gonzalo (2014): Salinity effects revealed by targeted and sustained underwater glider observations. Geophysical Research Letters, 42(17): 7 131-7 138.

Fang X J, Wang C X, Xu J J. 2013. Seasenal and interannual variations of the thermocline depth in the South China Sea. Transactions of Oceanology and Limnology, (3): 4555, https://doi.org/10.13984/j.cnki.cn37-1141. (Chinese)

Gill A E. 1984. On the behavior of internal waves in the wakes of storms. Journal of Physical Oceanography, 14(7): 1 129-1 151.

Guan F C, Xie Q H. 1984. The statistical characteristics of typhoon in the South China Sea. Marine Science Bulletin, 3(4): 19-27. (Chinese)

Guan S D, Zhao W, Huthnance J, Tian J W, Wang J H. 2014. Observed upper ocean response to typhoon Megi(2010) in the Northern South China Sea. Journal of Geophysical Research: Ocean, 119(5): 3 134-3 157, https://doi.org/10. 1002/2013JC009661

Guo J, Zhang T L, Zhang B, Mu Y K. 2018. Upper ocean response of Yongxing Island area to typhoon 'Kujira' in the South China Sea from multiple-satellite and fixedpoint observation. In: 2018 Progress in Electromagnetics Research Symposium. Toyama, Japan: IEEE, https:// ieeexplore.ieee.org/document/8597611/metrics\#metrics.

Herbeck L S, Unger D, Krumme U, Liu S M, Jennerjahn T C. 2011. Typhoon-induced precipitation impact on nutrient and suspended matter dynamics of a tropical estuary affected by human activities in Hainan, China. Estuarine Coastal and Shelf Science, 93(4): 375-388.

Iverson R L. 1997. Mesoscale oceanic phytoplankton patchiness caused by hurricane effects on nutrient distribution in the Gulf of Mexico. In: Andersen N R, Zahuranec B J eds. Oceanic Sound Scattering Prediction. Plenum Press, Plenum. p.767-778.

Knaff J A, DeMaria M, Sampson C R, Peak J E, Cummings J, Schubert W H. 2013. Upper oceanic energy response to tropical cyclone passage. Journal of Climate, 26(8): $2631-2650$.

Li X F, Zhang J A, Yang X F, Pichel W G, DeMaria M, Long D, Li Z W. 2013. Tropical cyclone morphology from space borne synthetic aperture radar. Bulletin of the American Meteorological Society, 94(2): 215-230.

Li Y H, Wang A J, Qiao L, Fang J Y, Chen J. 2012. The impact 
of typhoon Morakot on the modern sedimentary environment of the mud deposition center off the Zhejiang-Fujian Coast, China. Continental Shelf Research, 37: 92-100.

Li Y H, Xu X H, Yin X J, Fang J Y, Hu W Y, Chen J. 2015. Remote-sensing observations of Typhoon Soulik (2013) forced upwelling and sediment transport enhancement in the northern Taiwan Strait. International Journal of Remote Sensing, 36(8): 2 201-2 218, https://doi.org/10.10 80/01431161.2015.1035407.

Li Y X, Yang Y J, Sun L, Fu Y F. 2016. The upper ocean environment responses to typhoon Prapiroon (2012). In: Proceedings of SPIE 9261, Ocean Remote Sensing and Monitoring from Space. SPIE, Beijing, China. 92610Up, https://doi.org/10.1117/12.2069263.

Lin I I, Wu C C, Emanuel K A, Lee I H, Wu C R, Pun I F. 2005. The interaction of supertyphoon Maemi (2003) with a warm ocean eddy. Monthly Weather Review, 133(9): 2 635-2 649.

Lin I I. 2012. Typhoon-induced phytoplankton blooms and primary productivity increase in the western north Pacific subtropical ocean. Journal of Geophysical Research: Oceans, 117(C3): C03039, https://doi.org/10.1029/ 2011JC007626.

Lin I, Liu W T, Wu C C, Wong G T F, Hu C M, Chen Z Q, Liang W D, Yang Y, Liu K K. 2003. New evidence for enhanced ocean primary production triggered by tropical cyclone. Geophysical Research Letters, 30(13): 1 718, https://doi.org/10.1029/2003GL017141.

Liu J L, Cai S Q, Wang S G. 2011. Observations of strong nearbottom current after the passage of typhoon Pabuk in the South China Sea. Journal of Marine Systems, 87(1): 102108, https://doi.org/10.1016/j.jmarsys.2011.02.023.

Liu Z H, Xu J P, Sun C H, Wu X F. 2014. An upper ocean response to typhoon Bolaven analyzed with Argo profiling floats. Acta Oceanologica Sinica, 33(11): 90-101.

Mei W, Pasquero C. 2012. Restratification of the upper ocean after the passage of a tropical cyclone: A numerical study. Journal of Physical Oceanography, 42(9): 1 377-1 401.

Meissner T, Wentz F J. 2016. Remote Sensing Systems SMAP ocean surface salinities [Level 2C, Level 3 Running 8-day, Level 3 Monthly], Version 2.0 validated release. Remote Sensing Systems, Santa Rosa, CA, USA. Available at http://images.remss.com/papers/ rsstech/2016_Meissner_SMAP_SSS_Release_V2.pdf.

Price J F, Sanford T B, Forristall G Z. 1994. Forced stage response to a moving hurricane. Journal of Physical Oceanography, 24(2): 233-260.

Price J F. 1981. Upper ocean response to a hurricane. Journal of Physical Oceanography, 11(2): 153-175, https://doi. org/10.1175/1520-0485(1981)011<0153:UORTAH $>2.0$. $\mathrm{CO} ; 2$.

Rabe T J, Kukulka T, Ginis I, Hara T, Reichl B G, D'Asaro E A, Harcourt R R, Sullivan P P. 2015. Langmuir turbulence under hurricane Gustav (2008). Journal of Physical Oceanography, 45(3): 657-677.

Rayson M D, Ivey G N, Jones N L, Lowe R J, Wake G W,
McConochie J D. 2015. Near-inertial ocean response to tropical cyclone forcing on the Australian north-west shelf. Journal of Geophysical Research: Oceans, 120(12): $7722-7751$.

Shang S L, Li L, Sun F Q, Wu J Y, Hu C M, Chen D W, Ning X R, Qiu Y, Zhang C Y, Shang S P. 2008. Changes of temperature and bio-optical properties in the South China Sea in response to Typhoon Lingling, 2001. Geophysical Research Letters, 35(10): L10602, https://doi.org/10. 1029/2008GL033502.

Shay L K, Goni G J, Black P G. 2000. Effects of a warm oceanic feature on hurricane opal. Monthly Weather Review, 128(5): 1 366-1 383.

Shen J Q, Qiu Y, Zhang S W, Kuang F F. 2017. Observation of tropical cyclone induced shallow water currents in Taiwan Strait. Journal of Geophysical Research: Oceans, 122(6): 5 005-5 021.

Stramma L, Cornillon P, Price J F. 1986. Satellite observations of sea surface cooling by hurricanes. Journal of Geophysical Research: Oceans, 91(C4): 5 031-5 035.

Sun L, Li Y X, Yang Y J, Wu Q Y, Chen X T, Li Q Y, Li Y B, Xian T. 2014. Effects of super typhoons on cyclonic ocean eddies in the western north pacific: A satellite data-based evaluation between 2000 and 2008. Journal of Geophysical Research: Oceans, 119(9): 5 585-5 598, https://doi.org/10.1002/2013JC009575.

Sun L, Yang Y J, Fu Y F. 2009. Impacts of typhoons on the Kuroshio large meander observation evidences. Atmospheric and Oceanic Science Letters, 2(1): 45-50.

Sun L, Yang Y J, Xian T, Wang Y, Fu Y F. 2012. Ocean responses to typhoon Namtheun explored with Argo floats and multiplatform satellites. Atmosphere-Ocean, 50(S1): 15-26, https://doi.org/10.1080/07055900.2012.742420.

Wei J Z, Tang D L. 2011. A Statistical study of origin and intensity of tropical cyclone on the north western Pacific. Journal of Applied Statistics and Management, 30(3): 512-521. (in Chinese)

Wei W, Lien C C, Lin I I, Xie S P. 2015. Tropical cycloneinduced ocean response: a comparative study of the South China Sea and tropical northwest Pacific. Journal of Climate, 28(15): 5 952-5 968.

Xu H B, Tang D L, Sheng J Y, Liu Y P, Sui Y. 2018. Study of dissolved oxygen responses to tropical cyclones in the Bay of Bengal based on Argo and satellite observations. Science of the Total Environment, 659: 912-922

Yang B, Hou Y J, Li M. 2019. Response of the western north Pacific subtropical ocean to the slow-moving super typhoon Nanmadol. Journal of Oceanology and Limnology, 37(3): 938-956, https://doi.org/10.1007/ s00343-019-8114-0.

Yang L, Wang D X, Huang J, Wang X, Zeng L L, Shi R, He Y K, Xie Q, Wang S G, Chen R Y, Yuan J N, Wang Q, Chen J, Zu T T, Li J, Sui D D, Peng S Q. 2015. Toward a mesoscale hydrological and marine meteorological observation network in the South China Sea. Bulletin of the American Meteorological Society, 96(7): 1 117-1 135, https://doi.org/10.1175/BAMS-D-14-00159.1. 
Yang Y J, Sun L, Liu Q, Xian T, Fu Y F. 2010. The biophysical responses of the upper ocean to the typhoons Namtheun and Malou in 2004. International Journal of Remote Sensing, 31(17-18): 4 559-4 568.

Ye H J, Sheng J Y, Tang D L, Morozov E, Ali Kalhoro M, Wang S F, Xu H B. 2018. Examining the impact of tropical cyclones on air-sea $\mathrm{CO}_{2}$ exchanges in the Bay of Bengal based on satellite data and in-situ observations. Journal of Geophysical Research: Oceans, 124(1): 555-576, https:// doi.org/10.1029/2018JC014533.

Yue X X, Zhang B, Liu G Q, Li X F, Zhang H, He Y J. 2018. Upper ocean response to typhoon Kalmaegi and Sarika in the South China Sea from multiple-satellite observations and numerical simulations. Remote sensing, 10(3): 348, https://doi.org/10.3390/rs10020348.

Zeng L L, Wang Q, Xie Q, Shi P, Yang L, Shu Y Q, Chen J, Sui D D, He Y K, Chen R Y, Wang D X. 2015. Hydrographic field investigations in the Northern South China Sea by open cruises during 2004-2013. Science Bulletin, 60(6): 607-615.

Zhang B, Perrie W, Vachon P W, Li X F, Pichel W G, Guo J, He Y J. 2012. Ocean vector winds retrieval from C-band fully polarimetric SAR measurements. IEEE Transactions on
Geoscience and Remote Sensing, 50(11): 4 252-4 261, https://doi.org/10.1109/TGRS.2012.2194157.

Zhang B, Perrie W, Zhang J A, Uhlhorn E, He Y J. 2014a. High resolution hurricane vector winds from C-band dualpolarization SAR observations. Journal of Atmospheric and Oceanic Technology, 31(2): 272-286, https://doi. org/10.1175/JTECH-D-13-00006.1.

Zhang B, Perrie W. 2014b. Recent progress on high wind speed retrieval from multi-p4olarization SAR imagery: a review. International Journal of Remote Sensing 35(1112): 4 031-4 045.

Zhang G S, Zhang B, Perrie W, Xu Q, He Y J. 2014c. R. IEEE Transactions on Geoscience and Remote Sensing, 52(11): 7186-7194,https://doi.org/10.1109/TGRS.2014.2308839.

Zhao H, Han G Q, Zhang S W, Wang D X. 2013. Two phytoplankton blooms near Luzon Strait generated by lingering typhoon Parma. Journal of Geophysical Research, 118(2): 412-421.

Zheng G M, Tang D L. 2007. Offshore and nearshore chlorophyll increases induced by typhoon winds and subsequent terrestrial rainwater runoff. Marine EcologyProgress Series, 333: 61-74. https://doi.org/10.3354/ meps333061. 